\title{
25 Years on-an update on topics selected from the first volume of the Journal
}

\author{
- a review based on a symposium held on 6 January 1994 at the Queen Elizabeth // Conference Centre, London and \\ chaired by Professor J. G. Collee
}

Edited by B. I. DUERDEN

\section{Introduction}

The August 1993 issue of the Journal of Medical Microbiology marked the 25th anniversary of the launch of the Journal when the Pathological Society of Great Britain and Ireland split the Journal of Pathology and Bacteriology into two separate publications. At the winter meeting of the Society, in January 1994, the microbiology programme included a symposium based upon topics that had appeared in the first volume of the Journal, had been recurrent themes in the Journal throughout the 25 years, and were still of major significance in medical and veterinary microbiology-Haemophilus influenzae and the role of its capsule; Bordetella pertussis virulence and immunity; Escherichia coli enteritis in farm animals; staphylococcal virulence factors; and listeriosis in neonates and adults. This composite review- " 25 years on"-is based upon the presentations in that symposium.

The editors are grateful to the former chairman of the editorial board, Professor J. G. Collee, for his excellent contribution as chairman of the symposium. The chairmanship should have been shared with the present chairman of the board but he was a victim of another microbiological episode that marked this meeting of the Society. Of 27 members of the Society Committee and guests who attended the committee dinner $36 \mathrm{~h}$ before the symposium, 21 became acutely ill with enteritis clinically characteristic of infection with a Small Round Virus of Norwalk type. The incident was a typical point source outbreak, probably linked to contaminated shellfish, with the onset occurring between 36 and $48 \mathrm{~h}$ after the meal; symptoms of vomiting, diarrhoea, headache, fever, rigors and muscular aches ranged from moderate to incapacitating. One of the symposium speakers was also affected; he battled courageously to complete his assignment. The co-chairman was unable to leave his hotel room. The only consolation for my disappoint-

Accepted for publication 12 April 1994. ment has been my enjoyment as editor in preparing this review for publication.

HAEMOPHILUS INFLUENZAE-THE PAST, THE PRESENT AND THE FUTURE

\section{J. Zoe Jordens, T. Falla and Mary P. E. Slack}

Haemophilus Reference Laboratory, Public Health Laboratory, Level 7, John Radcliffe Hospital, Headington, Oxford $O X 39 D U$

In addition to being the 25th anniversary of the Journal of Medical Microbiology, 1993 was also the centenary of the first cultivation of Haemophilus influenzae by Pfeiffer. The historical landmarks in $H$. influenzae research have been comprehensively reviewed elsewhere ${ }^{1}$ but the most important are described below. The first documented observations of haemophili were by Koch, who described $H$. aegyptius (or $H$. influenzae biogroup aegyptius) from conjunctivitis in 1883. Ten years later, Pfeiffer described and cultured, with the aid of blood-supplemented agar, the bacillus he thought was the cause of influenza and it was officially named Haemophilus influenzae by the American Society of Bacteriologists in 1917. In 1931, Margaret Pittman identified capsulate and noncapsulate strains and showed that the former can be subdivided into six capsular types (a-f) distinguishable by serotyping with type-specific antisera. She also made the significant association between $H$. influenzae serotype $b(\mathrm{Hib})$ strains and meningitis around this time, which was very fortuitous as the description of influenza viruses in 1933 could otherwise have left $H$. influenzae as an organism without a disease. The 1950s saw a great deal of work by May and others on noncapsulate $H$. influenzae $(\mathrm{NCHi})$ and its association with respiratory disease. The possibility that these non-capsulate strains had been capsulate at the time of bronchial invasion had been raised and in the first issue of the Journal, in 1968, Turk and Holdaway investigated this possibility. They concluded that capsulate strains played no part in bronchiectasis. ${ }^{2}$

The last 25 years have seen many developments in 
microbiology which have increased our understanding of the pathogenesis and epidemiology of $H$. influenzae disease. The presence of a capsule has been shown to be a major virulence factor of Hib. ${ }^{3}$ The host's protective immune response is targetted against the Hib capsule and this is the basis of an effective vaccine. The genetic basis of capsule production has been characterised extensively and the mechanism whereby strains lose the ability to produce capsule is now established. ${ }^{4}$ Given these advances, if we were to ask a similar question today to that which Turk and Holdaway asked in their 1968 paper-i.e., "Are nonserotypable $H$. influenzae from bronchiectasis derived from capsulate strains?"- -how would our approach differ from theirs?

The laboratory identification of $H$. influenzae has changed very little in 25 years. Growth around commercially available disks containing factors $\mathrm{X}$ and $\mathrm{V}$ is the principal test for identification, and iridescence on Columbia agar supplemented with haemin, NAD and antisera has provided a simpler method of demonstrating the presence of capsule than the traditional Levinthal's agar. ${ }^{5}$ The capsular serotyping method described in 1931 is still used by the majority of laboratories which serotype $H$. influenzae isolates. However, this is one area in which modern technology is making a contribution. The polymerase chain reaction (PCR) has changed how the capsular type of $H$. influenzae is both determined and defined. The gene clusters responsible for capsulation (cap) in each of the six capsular types have been cloned. ${ }^{6,7}$ Capsule type-specific regions of each of the cap loci have been sequenced and primers designed which can be used for amplification in a PCR. ${ }^{7}$

One of the major advances of the past 10 years has been the unravelling of the structure of cap.$^{3,4,6-8}$ The salient features are shown in fig. 1 . The basic structure consists of three regions (1, 2 and 3). Region 2 is specific to each capsular type and is flanked by regions 1 and 3 which share sequence homology with the equivalent regions in all six capsular types. ${ }^{6}$ Region 1 contains the bex $A$ gene which is essential for export of capsular material and hence for the expression of capsule on the cell surface. ${ }^{3,4}$ In type $b$ strains the whole unit is flanked by copies of an insertion sequence element (IS1016) and is usually present as a duplication with a $1 \cdot 2-\mathrm{kb}$ deletion leaving only one functional bex $A$ gene. ${ }^{8}$ Homologous recombination occurs at a frequency of $0 \cdot 1-0.3 \%$ and reduces this duplication to the basic unit; however, this also results in the loss of the single functional bexA. ${ }^{4}$ The resultant strains are, therefore, genetically type $b$ but are capsule-deficient ( $\mathrm{Hib}^{-}$strains) and are non-serotypable by traditional serotyping methods.

The use of PCR primers for the capsule type-specific region enables the detection of type b-specific DNA in both $\mathrm{Hib}$ and $\mathrm{Hib}^{-}$strains. Primers designed within bex $A^{9}$ detect the intact bexA, which is necessary for capsule production. Therefore, $\mathrm{Hib}$ and $\mathrm{Hib}^{-}$strains can be distinguished by the amplification of the former with these bexA-derived primers. $\mathrm{Hib}^{-}$strains can be confirmed with PCR primers derived from DNA flanking bexA; bexB (in region 1) and IS1016 sequences. These primers amplify one product in $\mathrm{Hib}^{-}$ strains (corresponding to the deleted bex $A$ gene) but two products of different sizes in Hib strains (from the intact bex $A$ and the deleted bexA) (fig. 2). ${ }^{7}$ Therefore, PCR can be used to determine whether a nonserotypable strain is derived from a type $b$ capsulate strain (i.e., is a Hib strain).

The last 20 years have also seen advances in bacterial typing techniques. Some of those which have been advocated for $H$. influenzae include biotyping, outermembrane protein (OMP) subtyping, lipopolysaccharide analysis, whole-cell polypeptide profiles, restriction enzyme analysis, ribotyping and randomly amplified polymorphic DNA analysis. None of the current methods is very useful for Hib, as $80 \%$ of all strains are indistinguishable; it has a very clonal population genetics structure. ${ }^{10} \mathrm{NCHi}$ are much more heterogeneous and many techniques have been applied successfully to epidemiological investigations of putative outbreaks of infection. Most of these are electrophoretic techniques that give banding patterns which can be compared by eye or by computer. The large number of different banding patterns obtained means that these techniques are generally very good at discriminating between strains but it must be remembered that these are purely comparative techniques and the use of epidemiologically unrelated control strains is vital for interpretation of the results. ${ }^{11}$

The differences between capsulate and noncapsulate strains, in terms of the diseases with which they are associated, were well established in the $1930 \mathrm{~s}-1950 \mathrm{~s} .{ }^{1} \mathrm{Hib}$ is the major pathogen but it is important to remember that although strains of other serotypes and $\mathrm{NCHi}$ may be less virulent, they can cause invasive disease. A recent study of non-capsulate strains from invasive disease in neonates and children asked whether these strains played a part in invasive disease and if such strains were actually capsuledeficient type-b strains. ${ }^{12}$ Two of 21 strains, examined by the molecular techniques described above, were shown to be $\mathrm{Hib}^{-}$. Therefore, we have almost come full circle in 25 years, asking about the role of $\mathrm{Hib}^{-}$strains. In addition to the morbidity associated with $\mathrm{NCHi}$ as a cause of otitis media and exacerbations of chronic bronchitis, NCHi have also been associated with several hospital-acquired outbreaks of respiratory infection in the UK, ${ }^{11}$ the financial cost of which is not insignificant.

Although serious infections and hospital-acquired carriage or infection can be attributed to $\mathrm{NCHi}, \mathrm{Hib}$ is still the pathogen which generally concerns us most. The single most important contribution to the management of these infections over the past 25 years has undoubtedly been the introduction of an effective vaccine against $\mathrm{Hib}$ and the last few years have seen dramatic reductions in the incidence of Hib meningitis in countries where the vaccine has been introduced. 


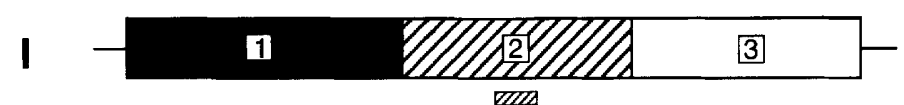

एखII

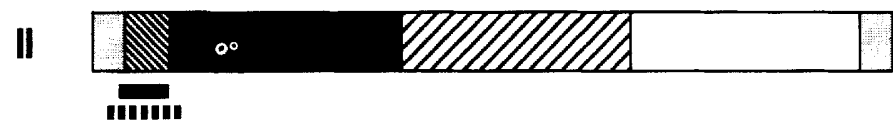

III

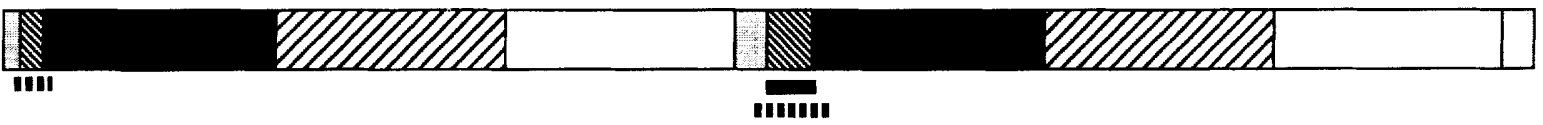

IV
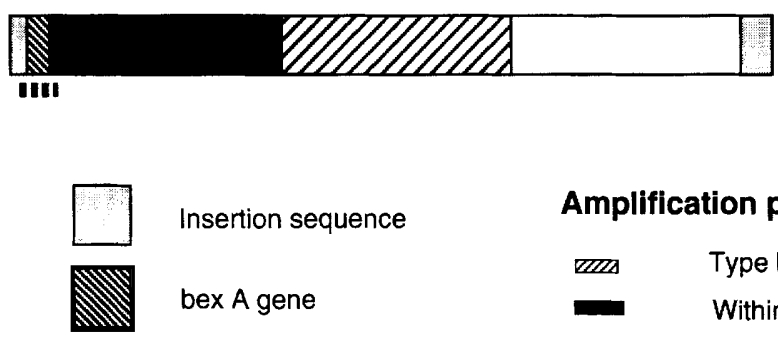

\author{
Amplification products:

Tyme $b$ specific
Within bex $A$
bex $A+$ flanking sequences

Fig. 1. Structure of cap in $\mathrm{Hib}$ and $\mathrm{Hib}^{-}$showing targets for amplification by PCR. I (top row), basic structure; II, basic unit flanked by IS 1016; III, duplication of basic unit with single functional bexA in Hib; IV, single copy of basic unit with detected bexA in Hib ${ }^{-}$.

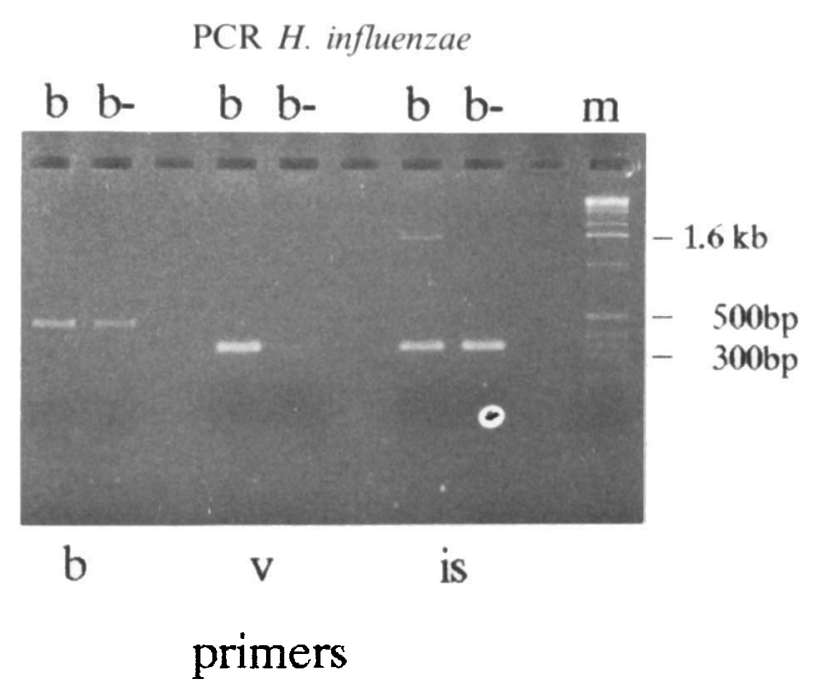

Fig. 2. Differentiation of $\mathrm{Hib}$ and $\mathrm{Hib}^{-}$by the PCR; b, Hib; $\mathrm{b}^{-}$, $\mathrm{Hib}^{-} ; \mathrm{m}=1-\mathrm{kb}$ size marker. The strains were amplified with primers for the capsule-specific type $\mathrm{b}$ region ( $\mathrm{b}$ primers); primers within bexA (v primers) or primers for IS 1016 and bexB (is primers); $\mathrm{Hib}^{-}$ gives no product with $v$ primers and lacks the larger product with is primers.

The impact of the Hib conjugate vaccine, introduced into the routine immunisation programme in the UK and Ireland in October 1992, has been dramatic. ${ }^{13}$ The number of cases of Hib meningitis and septicaemia in children $<1$ year old, notified to the PHLS Communicable Disease Surveillance Centre, decreased in 1993 to $16 \%$ of the number for previous years ( 38 compared with a mean of 233 for each of the preceding 3 years). However, some host populations respond differently to the different vaccines, e.g., Alaskan eskimos responded poorly to a Hib vaccine that was highly effective in Finland, so it is important to monitor the effect of the vaccine. A study to monitor Hib vaccine failures, set up by the British Paediatric Surveillance Unit, has been in progress since October 1992. Since the introduction of the vaccine in the British Isles there have been 17 reports of "true" vaccine failures, i.e., where Hib disease has occurred when protective immunity should have developed (at least 1 week after a child aged $<1$ year has received at least two doses of Hib vaccine, or at least 3 weeks after a single dose of $\mathrm{Hib}$ vaccine in children aged $\geqslant 1$ year). There have also been 47 "apparent" vaccine failures, when disease occurred after a single dose of vaccine and before protective immunity could have developed. With the PCR techniques described above, none of the strains from these patients was $\mathrm{Hib}^{-}$. However, the vaccine is not expected to have any effect on infection with capsular types other than type b or non-capsulate strains, which are important causes of serious disease in other parts of the world and H. influenzae (Hib and $\mathrm{NCHi}$ ) is expected to remain an important cause of invasive disease in adults. Before the introduction of Hib immunisation in the UK, c. $10 \%$ of invasive disease was caused by NCHi and $1.7 \%$ by capsulate strains of serotypes other than $b .{ }^{13}$ This is even more striking in developing countries where other serotypes (notably a) and NCHi are a significant cause of meningitis and pneumonia. ${ }^{14,15}$ Therefore, a vaccine against serotypes other than $\mathrm{b}$ and $\mathrm{NCHi}$ would be desirable.

So, what does the future hold? Will there be a vaccine against non-capsulate strains? NCHi are very heterogeneous so it will not be as straightforward as the Hib vaccine story. Several immunogenic targets have been investigated and there has been some work on OMP-directed vaccines. Many potential targets, 
such as OMP P2, are too specific (strain specific) but several other proteins which are conserved between strains have also been advocated. ${ }^{16}$ Other possibilities include iron-regulated OMPs such as transferrinbinding proteins (TBPs), but studies of antigenic relationships amongst TBPs have so far been performed with only a very limited number of strains ( $\mathrm{K}$. J. Towner, personal communication).

In the last 25 years, much has been learnt about the genetic structure of capsule production and the pathogenicity of NCHi and there is now an effective vaccine against $\mathrm{Hib}$. The vaccine has reduced the concerns of the 1970s and 1980s about the increasing antibiotic resistance in this organism. However, it remains important to remember that $H$. influenzae other than type $b$ can cause problems and the organism should not be forgotten simply because Hib vaccine has been introduced.

\section{BORDETELLA PERTUSSIS - 25 YEARS ON}

\section{R. Parton}

Department of Microbiology, University of Glasgow, Glasgow G12 $8 Q Q$

The paper by Holt and Spasojevic ${ }^{17}$ in the first issue of the Journal of Medical Microbiology provides a useful reference point for an update on Bordetella pertussis and pertussis research. It incorporated three topics - the search for $B$. pertussis protective antigens, antigenic variation and animal models of pertussiswhich form the basis of this brief and, therefore, selective review. The theme of their paper was to examine the role of particular surface antigens in the protective potency of $B$. pertussis cell suspensions in the mouse intracerebral challenge test. The whole-cell vaccines in use at that time were known to be reactogenic and there was much interest in identifying the protective antigens in order to separate them from the toxic components of the bacterium. In the last 25 years, various purified $B$. pertussis antigens have been shown to be protective in animal models and are candidate vaccine components, but the search goes on. Holt and Spasojevic were able to induce changes in the surface antigens of $B$. pertussis by growth on different media. Much is now known about the molecular mechanisms of this and related variation processes in $B$. pertussis but their significance is obscure. The mouse intracerebral challenge test may seem rather inappropriate for estimating the protective efficacy of vaccines for a respiratory disease of man, but the test is still in use today. All animal models of pertussis have their shortcomings but the recently described coughing rat model ${ }^{19-20}$ may provide new opportunities for studying pathogenic mechanisms and vaccine efficacy.

Twenty-five years ago, the epidemiology of pertussis in the UK was similar to that seen today, with a low level of annual notifications and the disease controlled by a high uptake of whole-cell vaccine. ${ }^{21}$ In the intervening period, there was a dramatic change to this picture. Fig. 3 shows the steady decline in the incidence and severity of pertussis in England and Wales, with the introduction of immunisation in the 1950s. However, from 1974 , following widely publicised concerns over the safety of pertussis vaccines, uptake rates fell sharply, from $>80 \%$ to $30 \%$ in some areas. The value of pertussis vaccination, especially in view of the low incidence of the disease at the time, was fiercely debated. As can be seen, this was followed by major epidemics of pertussis around 1978 and 1982, with younger, unvaccinated children being most affected. As vaccine uptake has recovered, control has once again been established. The cyclical nature of the disease, with epidemic peaks every $3-4$ years, is also evident from fig. 3 but it is not clear why the frequency of these cycles has not been altered by the introduction of immunisation or by recent changes in vaccine uptake. One suggestion is that whole-cell vaccines provide better protection against the disease than against infection and that vaccination has had little effect on the prevalence of $B$. pertussis in the population. ${ }^{22}$

Whole-cell vaccines are undoubtedly reactogenic and different preparations may vary. Swelling and redness at the site of injection are common. More severe reactions such as high fever, persistent crying and seizures are less frequent, but all are transient. ${ }^{23}$ An alleged association between pertussis vaccination and permanent neurological damage or death has never been demonstrated conclusively and, if these events do occur, they must be very rare. ${ }^{24,25}$ In spite of the reactogenicity of the vaccine, it is generally agreed that the benefits of controlling pertussis and its associated hazards far outweigh the risks.

It is interesting to note that the proportion of adults with pertussis is increasing steadily. In Scotland, for example, $10 \%$ of all notified cases are now in adults ( $>15$ years old) compared with $2 \% 25$ years ago. ${ }^{26}$ Several factors may be contributing to the increase, such as improved diagnosis and waning immunity in adults, but the non-vaccinated cohort from the $1970 \mathrm{~s}$ is now entering this age group.

The problems with pertussis vaccine have been mirrored in other parts of the world but, where there is a high vaccination rate, the disease is controlled. However, pertussis still causes severe morbidity and mortality in unvaccinated communities with 60 million cases and $>0.5$ million deaths per annum estimated in 1986. ${ }^{27}$ Fortunately, increasing global immunisation coverage by schemes such as the WHO Expanded Programme on Immunization is steadily reducing these figures.

Whatever the rights and wrongs of the pertussis vaccine debate, it provided a major stimulus for pertussis research and for the development of new pertussis vaccines devoid of side effects. The aim was to prepare defined acellular vaccines which would be fully characterised in terms of their antigenic composition and in which the toxic components of whole 


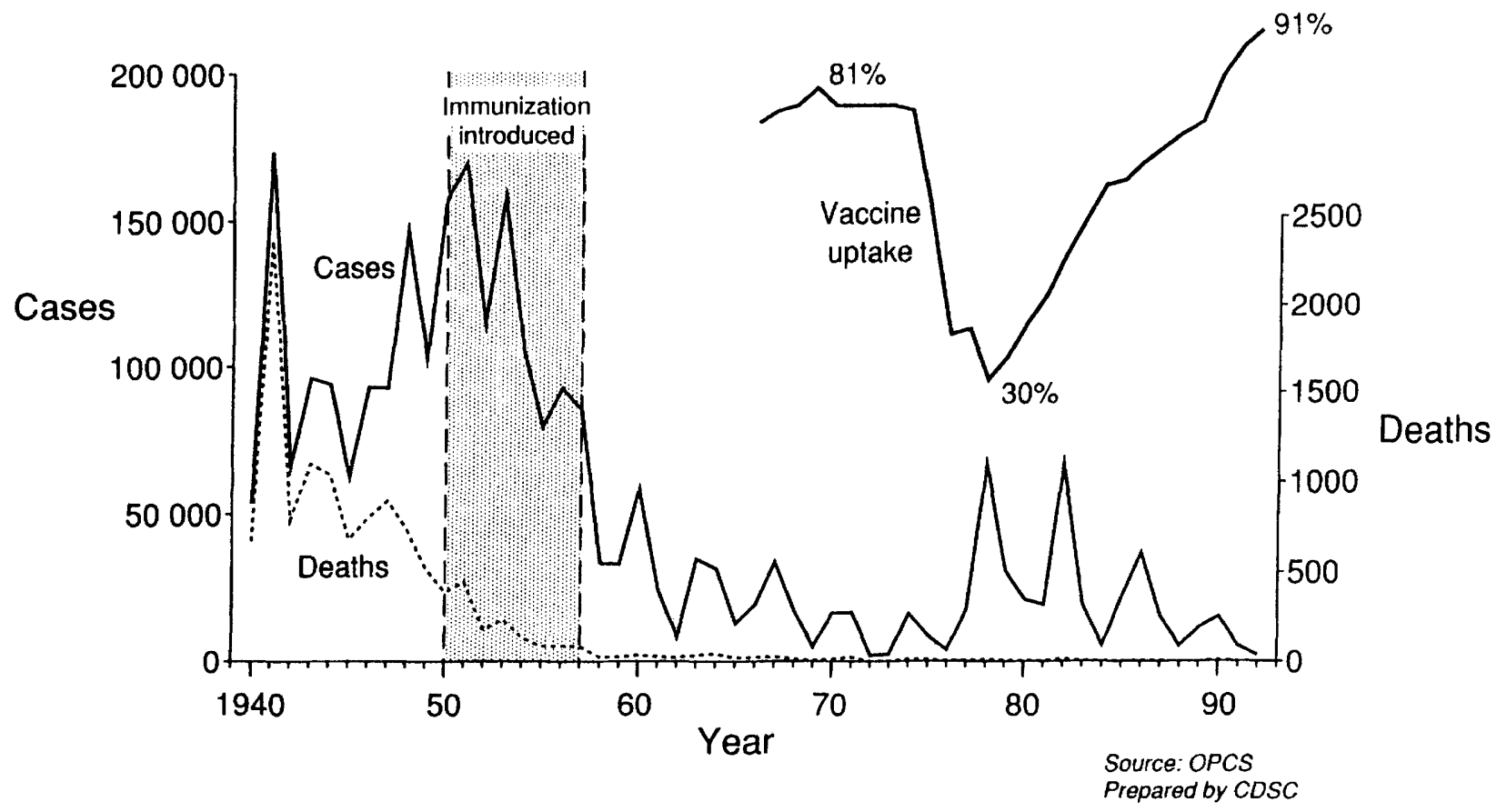

Fig. 3. Whooping cough notifications: cases and deaths, England and Wales, 1940-1992.

cells would be absent or inactivated. A less reactogenic vaccine would also promote the acceptability of pertussis vaccination worldwide and could be used to boost the waning immunity of adults. Another aim was to improve protective efficacy and to prevent infection as well as disease, an essential requirement for any future pertussis eradication programme. In the search for pertussis protective antigens, certain problems have had to be addressed. The pathogenesis of pertussis is complex and identification and characterisation of the virulence factors of $B$. pertussis have been troublesome. A major factor has been the shortcomings of the various animal models available, although intracerebral and intranasal challenge tests in mice have provided much useful information. ${ }^{28}$

Twenty-five years ago, several biologically-active factors of $B$. pertussis had already been described. The idea was just beginning to emerge that some of these, such as the histamine-sensitising factor, leucocytosispromoting factor, heat-labile adjuvant and a protective antigen for mice, were in fact one and the same, a component now known as pertussis toxin (PT) ${ }^{29}$ In recent years, remarkable insight into the virulence properties of $B$. pertussis has been achieved by the application of modern molecular techniques. In fact, due largely to the pioneering work of Weiss and Falkow, ${ }^{30}$ B. pertussis has become almost a model system for this approach to the study of bacterial virulence. Their method for transposon mutagenesis with a suicide plasmid to deliver transposon $\operatorname{Tn} 5$ into the $B$. pertussis chromosome has led to the identification of several genes encoding virulence factors or regulating the expression of virulence. Many of these have now been cloned, sequenced and expressed in other bacteria. In addition, strains engineered with precise mutations have been used to investigate the effect of loss of individual factors on the ability to colonise and cause disease in experimental animals.

Current information on $B$. pertussis virulence factors is summarised in table I. Several toxins and adhesions for different mammalian cells and tissues have been identified and purified. ${ }^{31}$ It is still not clear why (or whether) B. pertussis needs all of these and what role they play in pathogenesis, but the results suggest that the organism has a number of alternative strategies for ensuring its survival and propagation within the host population. ${ }^{32}$ In some cases, these factors have been protective both in mouse models of infection and in recent field trials of acellular vaccines in human infants.

The factor that has received most attention as a vaccine constituent is PT. It has a remarkable range of activities in vitro and in vivo; ${ }^{31}$ e.g., it is an ADP ribosyltransferase, like some other bacterial toxins, but it is also a haemagglutinin and a T-cell mitogen. Furthermore, PT causes leucocytosis, which is a characteristic feature of pertussis, and enhancement of insulin secretion and inhibition of adrenaline hyperglycaemia which have also been noted in the disease in man. In toxoided form, PT can be protective but, untoxoided, it has a range of potentially harmful effects on experimental animals, such as histamine sensitisation and potentiation of anaphylaxis, and it is lethal for mice in $\mu \mathrm{g}$ amounts. PT is a subunit toxin with an enzymic moiety, the S1 or A subunit, and a complex B subunit responsible for binding to target cells and inserting the $\mathrm{S} 1$ subunit into the cytoplasm. ${ }^{33}$ The haemagglutinating and mitogenic activities of PT are due to the B subunit acting on the target cell surface but most of the other effects result from activity of the S1 subunit within the target cell. There it interferes with particular $G$ proteins and trans- 
Table 1. Virulence factors and protective antigens of $B$. pertussis

\begin{tabular}{|c|c|c|c|}
\hline \multirow[b]{2}{*}{$\begin{array}{l}\text { Virulence factor } \\
\text { and synonyms }\end{array}$} & \multirow[b]{2}{*}{$\begin{array}{l}\text { Possible role in } \\
\text { natural infection }\end{array}$} & \multicolumn{2}{|c|}{ Protective activity in } \\
\hline & & mouse* & $\operatorname{man}$ \\
\hline $\begin{array}{l}\text { Pertussis toxin } \\
\text { Leucocytosis-promoting factor, } \\
\text { histamine-sensitising factor, islets- } \\
\text { activating protein etc. }\end{array}$ & $\begin{array}{l}\text { Adhesion, inhibition of immune effector } \\
\text { cells, leucocytosis promotion, other } \\
\text { systemic toxic effects }\end{array}$ & + & + \\
\hline Filamentous haemagglutinin & Adhesion & + & + \\
\hline $\begin{array}{l}\text { Agglutinogens } 2 \text { and } 3 \\
\text { Fimbrial or serotype antigens }\end{array}$ & Adhesions & + & + \\
\hline $\begin{array}{l}\text { 69-kDa Outer-membrane protein } \\
\text { Pertactin }\end{array}$ & Adhesion & + & $?$ \\
\hline $\begin{array}{l}\text { Adenylate cyclase toxin } \\
\text { Cyclolysin }\end{array}$ & Inhibition of immune effector cells & + & $?$ \\
\hline $\begin{array}{l}\text { Heat-labile toxin } \\
\text { Dermonecrotic toxin }\end{array}$ & Local damage & - & - \\
\hline Tracheal cytotoxin & Ciliary damage & $?$ & $?$ \\
\hline $\begin{array}{l}\text { Lipopolysaccharide } \\
\text { Endotoxin, lipo-oligosaccharide }\end{array}$ & Fever & - & - \\
\hline
\end{tabular}

*Protection against challenge with $B$. pertussis by the intranasal route. Only PT is protective by the intracerebral route. ${ }^{28}$

Table II. Examples of defined acellular pertussis vaccines

\begin{tabular}{|c|c|c|c|}
\hline Vaccine type & Composition & Toxoiding process & Stage of development \\
\hline \multirow[t]{3}{*}{ 1st generation } & $\begin{array}{l}\text { PTd and FHA as main components, } \\
\text { co-purified from culture supernate }\end{array}$ & & \\
\hline & PTd + FHA ( + AGGs + other $)$ & Formaldehyde & $\begin{array}{l}\text { Routine use in Japan since } 1981 \\
\text { Licensed as booster in USA, 1991 }\end{array}$ \\
\hline & $\mathrm{PTd}+\mathrm{FHA}$ & Formaldehyde & $\begin{array}{l}\text { Routine use in Japan since } 1981 \\
\text { Swedish phase } 3 \text { trials } 1986\end{array}$ \\
\hline \multirow[t]{3}{*}{ 2nd generation } & $\begin{array}{l}\text { Individually-purified and chemically- } \\
\text { inactivated components }\end{array}$ & & \\
\hline & PTd & Formaldehyde & Swedish phase 3 trials 1986 \\
\hline & PTd + FHA + AGGs + pertactin & Glutaraldehyde & Phase 3 trials in progress \\
\hline \multirow[t]{2}{*}{ 3rd generation } & $\begin{array}{l}\text { Containing recombinant proteins } \\
\text { from } B . \text { pertussis or other organisms }\end{array}$ & & \\
\hline & Recombinant PTd + FHA + pertactin & Genetic & Phase 3 trials in progress \\
\hline
\end{tabular}

Based on a table from Hewlett and Cherry. ${ }^{37}$

membrane signalling, resulting in a range of different effects on different host cells. PT has now been rigorously purified and, in chemically-toxoided form, is one of the major components in almost all of the new acellular vaccines.

At around the same time as these purification and characterisation studies other investigators identified the genes for PT expression and sequenced the PT operon. ${ }^{34,35}$ This breakthrough enabled Rappuoli and co-workers ${ }^{36}$ to map the important regions of the molecule such as those in the $\mathrm{S} 1$ subunit responsible for enzymic (toxic) activity and immunogenicity in terms of the B-cell and T-cell epitopes required for protection. With this information, they were then able to use site-directed mutagenesis to alter the molecule. It was found that by changing just two amino acids (Arg 9 $\rightarrow$ Lys and Glu 129 $\rightarrow$ Gly), they were able to eliminate toxic activity completely while retaining immunogenicity. This genetic toxoid is more immunogenic than conventional chemical toxoids and highly protective in mice because it is structurally and antigenically indistinguishable from the native toxin. Chemical detoxification with agents such as formaldehyde damages the structure and epitopes of the molecule and yet may still allow reversion to toxicity. By contrast, the genetic toxoid is irreversibly toxoided.

The first of the defined acellular vaccines ${ }^{29.37}$ were developed by Sato et al. ${ }^{38}$ in the late 1970s. Such "first generation" pertussis vaccines (table II) contain toxoided PT (PTd) and filamentous haemagglutinin (FHA), one of the adhesins, as their main components. However, because of the way in which these vaccines are prepared, they also contain smaller amounts of other components as contaminants. Toxoiding of PT 
is usually done with formaldehyde. Several such vaccines with different compositions have been used in place of whole-cell vaccines in Japan since 1981. All available evidence indicates that they are effective and less reactogenic than the whole-cell products but they have never been subjected to rigorous clinical trials in Japan. "Second generation" vaccines contain highly purified ingredients and range from a monocomponent PTd vaccine to a multicomponent vaccine containing PTd with the adhesins FHA, agglutinogens (AGGs) and pertactin.

Two of these vaccines, a monocomponent PTd and a two-component PTd + FHA vaccine were used in a large, double-blind, placebo-controlled field trial in 1986-1987 in Sweden, ${ }^{39}$ a country where pertussis was prevalent as a result of a policy not to immunise against the disease. Their reactogenicity was low, as expected, but efficacy results were disappointing. They were less protective against culture- or serologicallyconfirmed pertussis than would have been expected for a whole-cell vaccine. However, both vaccines gave good protection against severe disease and provided evidence that PTd alone or with other antigens could make effective vaccines.

Further trials are now in progress in Sweden and elsewhere of other vaccine formulations, examples of which are shown in table II. One particularly promising vaccine is a "third generation" product containing the recombinant PTd (genetic toxoid) mentioned above, and phase 3 trials are in progress in Italy. If the results, expected in 1995-1996, are good, there may be little impetus for the development of further generations of pertussis vaccines, such as those containing immunogenic peptides or live attenuated organisms.

In addition to the search for protective antigens, the pertussis paper in the first issue of the Journal was concerned with antigenic variation. B. pertussis is, potentially, a highly adaptable organism. ${ }^{32}$ It can undergo serotype variation in which expression of surface antigens is altered by mutational events. It can also alternate between virulent and avirulent forms either by mutation (phase variation) or by a freelyreversible phenotypic change (antigenic modulation) in response to in-vitro growth conditions. The mechanisms of these variation processes are starting to become clear. ${ }^{40}$ For example, the organism has mutational "hot spots" in certain regions of the genome that promote frameshifts to allow serotype variation and phase variation at fairly high frequency. Antigenic modulation is controlled by a twocomponent sensor-regulator system with homology to systems in other bacteria. A surface-located sensor protein, BvgS, is thought to detect environmental changes, e.g., in temperature or ionic conditions, and transmit a signal to the response regulator BvgA, a cytoplasmic DNA-binding protein. Under normal growth conditions, BvgA activates transcription of the well-characterised virulence genes (vir-activated genes), either directly or indirectly, and at the same time represses another set of genes (vir-repressed genes) whose products have not yet been characterised.

It is not entirely clear why $B$. pertussis needs these variation processes. Serotype variation is presumably a strategy for evading the host immune response and vaccine-induced immunity appears to have a serotypespecific component, ${ }^{5}$ as originally proposed by Preston. ${ }^{41}$ With regard to antigenic modulation, many pathogens can detect changes in their environment and use the signals to regulate virulence factor expression at different stages in the disease process or at different sites in the host. But what are these stages or sites for $B$. pertussis? Until recently, it was thought that $B$. pertussis resides exclusively on the ciliated epithelium of the human respiratory tract but recent evidence suggests that it may have an intracellular stage. ${ }^{42}$ It is capable of invading and surviving within mammalian cells, e.g., macrophage and tissue culture cell lines, perhaps again to avoid the host immune response. Switching off the expression of virulence genes is also a way of adapting to life outside the host, but no alternative host or site has been reported for $B$. pertussis. All Bordetella spp. are generally regarded as obligate parasites of the respiratory tract of mammals and birds but recent evidence has changed this view. $B$. parapertussis was thought to be purely a parasite of man, like $B$. pertussis, but has now been isolated from healthy and pneumonic sheep. ${ }^{43}$ In addition, $B$. bronchiseptica can survive and grow in natural waters. $^{44}$

The final part of this update concerns a new animal model of pertussis, namely the coughing rat model, ${ }^{18-20}$ which is being developed in our laboratory. Study of the cough is important because of its central role in the disease process. Many of the respiratory complications and central nervous system disturbances associated with pertussis are thought to result from the severe coughing. ${ }^{23}$ The model is based on earlier observations on the induction of coughing in rats infected intrabronchially with $B$. pertussis ${ }^{45,46}$ In our experiments, the rats are infected with $B$. pertussis encased in fine agarose beads and the intermittent paroxysmal coughing is recorded and analysed with soundactivated tape recorders. The animals also show leucocytosis and, in young rats, significant retardation of weight gain. Wild-type or phase I B. pertussis strains all induced coughing paroxysms whereas a phase variant, lacking all of the major virulence factors, did not. More significantly, a transposon-insertion mutant lacking only PT did not induce coughing. Therefore, it appears that of all the virulence factors produced by $B$. pertussis, PT appears to have a central role in the disease process, as suggested by Pittman ${ }^{47}$ some years ago. Since the rat is the only conveniently accessible laboratory animal in which $B$. pertussis produces paroxysmal coughing, the model has much potential for further study of the mechanisms of cough production and immunity in pertussis, including the investigation of virulence factors and acellular vaccines. 
I thank Elizabeth Miller for providing the figure and A. Wardlaw for helpful comments on the manuscript.

ESCHERICHIA COLI INFECTION IN FARM ANIMALS- 25 YEARS OF PROGRESS

C. Wray, M. J. Woodward and I. M. McLaren

Central Veterinary Laboratory, New Haw, Addlestone, Surrey $K T 153 N B$

During the 1960s, the role of Escherichia coli as an enteric pathogen in farm animals was clearly established. The work of Smith and his co-workers redefined Koch's postulates to take account of developments in microbial genetics. ${ }^{48}$ The mechanisms of adherence of $E$. coli and the biochemical effects of its toxins are now being clarified with the advent of sophisticated molecular and cellular biological tools. The purpose of this brief review is to highlight the developments in the veterinary field since the first publication of this Journal in 1968.

\section{The E. coli toxins}

Heat-labile enterotoxin (LT) exists as a high-mol. wt protein that resembles cholera toxin (CT) both pharmacologically and immunologically and is not inactivated by heating at $60^{\circ} \mathrm{C}$. A wide variety of different $E$. coli serogroups of porcine origin produce LT; these serogroups usually possess the F4(K88) fimbrial adhesin. The LT of porcine origin has common and unique antigenic determinants when compared with LT produced by human isolates of $E$. coli. Another enterotoxin (LT2) was detected in E. coli isolates from cattle and, while it shared many biological properties with LT1, it was not neutralised by antiserum to CT or LT1. LT2, like LT1, activates adenylate cyclase in eukaryotic cells but, in contrast to LT1 whose genes are plasmid encoded, it genes appear to be on the chromosome. ${ }^{49}$

Heat-stable enterotoxins (ST) are low-mol.wt proteins that resist heating at $100^{\circ} \mathrm{C}$ for $30 \mathrm{~min}$. Two types of ST have been described. STa, which is methanol soluble, is active in the gastrointestinal tract of calves, sheep and neonatal mice and is usually produced by $E$. coli strains that express the fimbrial adhesins F5(K99), F41 and F6(987P). STas from $E$. coli isolates from man, cattle and pigs have been purified and, although they share similar chemical and biological activities, there is slight molecular heterogeneity. STb, which is methanol insoluble, induces intestinal secretion in both the newborn and the weaner pig and has no apparent toxicity in mice. It is usually associated with $\mathrm{LT}+E$. coli strains that express the F4 fimbrial adhesin, although other combinations of toxin and fimbriation have been described. ${ }^{50}$

Verocytotoxigenic $E$. coli (VTEC) strains were first described in $1977 .{ }^{51}$ The cytotoxin, similar to Shiga toxin, destroys Vero cell monolayers and possesses two polymorphs VT1 and VT2 (also called SLT1 and SLT2). VTEC have been isolated from diseased calves and pigs and in the latter species they are often associated with oedema disease. Although VT from porcine $E$. coli isolates share considerable genetic homology, as demonstrated by hybridisation with a VT2 probe, the cytotoxin activity is not neutralised to the same extent by antitoxin to VT2. Differentially described as VT2e, this toxin differs from VT2 in being inactive on HeLa cells, more heat-labile and not being phage-mediated like VT1 and VT2. DNA transfer experiments showed that the verocytotoxicity of oedema disease strains could be transferred to $E$. coli K12 and that pigs inoculated with the transconjugant developed the clinical and pathological lesions of the disease. $^{52,53}$

Cytotoxic necrotising Factor (CNF) was first described in $E$. coli isolates from $\operatorname{man}^{54}$ and has been detected subsequently in several $E$. coli serotypes isolated from farm animals. ${ }^{55} \mathrm{CNF}$ is a heat-labile cytotoxin that causes multinucleation and giant cell formation in Vero, HeLa and CHO cells and necrosis when injected intradermally into rabbits. Although $\mathrm{CNF}^{+} E$. coli strains have been detected in a wide range of serogroups from different clinical conditions in farm animals, most isolates belong to a small range of serogroups. ${ }^{55} \mathrm{~A}$ second type of $\mathrm{CNF}$, which is only partially neutralised by antitoxin to $\mathrm{CNF} 1$ has been described, ${ }^{56}$ and while both types share considerable genetic homology, CNF1 is encoded chromosomally ${ }^{57}$ and CNF2 is encoded on the transmissible Vir plasmid. ${ }^{58}$

\section{Fimbrial antigens and putative colonisation factors}

Several specific fimbrial adhesins, whose attachment to erythrocytes and epithelial cells, or both, is not impaired by D-mannose, have been shown to be important virulence factors in the pathogenesis of diarrhoea in farm animals. Some, such as F4, F5, F6 and F41 fimbriae, were identified many years ago ${ }^{59}$ while others (table III) have been recognised more recently. Whether some of the more recently identified surface antigens are true colonisation factors awaits clarification and there is also an urgent need for a standard nomenclature and a reference centre. Colonisation factors are associated with ETEC, VTEC and bacteraemic $E$. coli strains and the genes may be encoded on plasmids or the chromosome. Whereas some fimbrial antigens are expressed in vivo, the antigen may not be expressed, or only partially expressed, in culture.

Some pigs show genetic resistance to intestinal colonisation by ETEC, thus $\mathrm{F}^{+}$and $\mathrm{F} 107^{+}$strains do not adhere to isolated brush border preparations from all piglets. ${ }^{69,70}$ F41 fimbriae, although antigenically distinct from the F4 antigen, share considerable gene sequence homology in those genes associated with processing the antigen. Likewise, some fimbriae often occur in association with others, e.g., F5 with F41, and Cs31a with F165 and F5 antigens.

A novel class of $E$. coli surface structures, "Curli", 
Table III. Recently described putative adhesive fimbrial antigens

\begin{tabular}{|c|c|c|}
\hline $\begin{array}{l}\text { Antigen } \\
\text { designation }\end{array}$ & $\mathrm{O}$ group & $\begin{array}{c}\text { E. coli type/ } \\
\text { disease syndrome }\end{array}$ \\
\hline $\mathrm{F} 42^{60}$ & 8 & ETEC \\
\hline $\mathrm{F} 17^{61}$ & $8,9,15,78,101,86$ & ETEC/septicaemia in cattle \\
\hline $\mathrm{F} 107^{62}$ & $139,138,141$ & PWD (porcine VTEC) \\
\hline $\mathrm{F} 165^{63}$ & $115,78,9,101,15$ & Septicaemia in pigs \\
\hline & $7,117,4,18,149$ & Septicaemia in cattle \\
\hline $\mathrm{CS} 31 \mathrm{a}^{64}$ & $\begin{array}{r}18,17,78,117,23 \\
134,9,157,87,161\end{array}$ & Septicaemia in cattle \\
\hline$M 326^{65}$ & 65 & Porcine VTEC \\
\hline $8813^{66}$ & $25,108,138,141,147,157$ & Porcine ETEC \\
\hline $\mathrm{C} 1213^{67}$ & $20,153,78,9$ & Diarrhoea in cattle \\
\hline $\mathrm{F} 11^{68}$ & $1,2,78$ & Septicaemia in poultry \\
\hline
\end{tabular}

which are morphologically and biochemically distinct from other surface appendages, have been described recently on strains isolated from bovine mastitis. ${ }^{71}$ Curli are fibronectin- and laminin-binding fibres, expressed at temperatures below $37^{\circ} \mathrm{C}$ when grown on CFA medium. Whether Curli are true virulence factors is unclear, but they share homology with similar thin aggregative fimbriae (SEF17) found on salmonellas.

\section{E. coli disease in farm animals}

Colibacillary diarrhoea and toxaemia are well described but the pathogenesis of porcine post-weaning diarrhoea (PWD) is more complex. ${ }^{72}$ PWD may be attributed to weaning-associated factors interacting with the organism: these include stress at weaning, decreased gastric $\mathrm{pH}$ and the lack of lactogenic immunity. Rotavirus, often in conjunction with haemolytic E. coli, has also been associated with PWD, as has hypersensitivity of the intestinal mucosa to dietary antigens. However, the one unifying finding is the marked increase in numbers of haemolytic $E$. coli that occurs 2-7 days after weaning.

\section{Diseases caused by EPEC}

$E$. coli strains that attach intimately to enterocytes of the intestinal mucosa with loss (effacement) of microvilli are known at attaching and effacing $E$. coli (AEEC). The formation of the characteristic cup and pedestal, which involves the eae gene, has been reviewed..$^{73}$ Many strains of AEEC, which also produce VT, have been isolated from a wide range of clinical conditions and the characteristic lesions and blood-stained diarrhoea have been reproduced experimentally ${ }^{55}$ A survey of $E$. coli cultures ${ }^{74}$ found that $4.7 \%$ of 3595 porcine isolates, $2.8 \%$ of 1383 bovine isolates and $6.1 \%$ of 407 ovine isolates produced VT. A longitudinal study of $E$. coli in two cohorts of calves found that 91 of 171 isolates were VTEC and $20-80 \%$ of the animals excreted VTEC at any one time, often in association with diarrhoea. ${ }^{75}$ Examination of $296 \mathrm{E}$. coli isolates from calves with diarrhoea $^{76}$ found that 70 hybridised with the eae probe and, of these, 50 hybridised with the VT1 probe, one with the VT2 probe and three produced both VT1 and VT2. Ten eae positive isolates gave negative results with both VT probes.

\section{Zoonotic aspects of VTEC production}

Verocytotoxin-producing $E$. coli, frequently belonging to serogroup O157, have been found to be associated with a number of disease syndromes in man, such as haemorrhagic colitis (HC) and haemolytic uraemic syndrome (HUS). Such strains have also been isolated from the faeces of cattle by several investigators, ${ }^{77}$ and the frequent association between VTEC infection in man and the consumption of beef and dairy products suggests that cattle are a reservoir of VTEC. Following an epidemiological investigation of two sporadic cases of HUS associated with milk, VT-producing isolates, which included E. coli $\mathrm{O} 157$, were identified in $13(8.4 \%)$ of 154 healthy dairy cattle. E. coli $\mathrm{O} 157$ has also been isolated from cattle in England ${ }^{78}$ and in Scotland the organism was isolated from scouring calves. ${ }^{79}$

In cattle infected with $E$. coli $\mathrm{O} 157$, the organisms are usually present in the faeces in small numbers. The extent of the bovine reservoir is unknown. However, with more sensitive techniques of isolation, Chapman found that infection was widespread in one herd associated with milk-borne infection (personal communication).

\section{Systemic colibacillosis}

Systemic colibacillosis occurs frequently in calves, lambs and poultry although it is less frequent in pigs. Bacteraemic strains of $E$. coli pass through the mucosa of the alimentary or the respiratory tract and enter the blood stream which may result in either a generalised or localised infection. Bacteraemic E. coli strains are able to resist the host's defence mechanisms and are able to survive in blood and peritoneal fluid. ${ }^{72}$ The genetic determinants for serum resistance and colicin $\mathrm{V}$ production are closely linked. Also, plasmid genes associated with $\mathrm{Col} \mathrm{V}$ encode a specific high affinity 
iron-uptake mechanism which consists of aerobactin, a hydroxamate siderophore and an inducible outermembrane protein that acts as a receptor for the ferricaerobactin complex. A good correlation has been shown between aerobactin production and invasiveness of $E$. coli isolates from animals.

Another independent plasmid has been shown to be associated with a lethal toxin, CNF2, and the production of a surface antigen, the genes of which hybridise with F17 probes. The persistence of these plasmid-bearing $E$. coli in the avian respiratory tract may be associated with the presence of pili such as the putative CS31a and F165 adhesin which enable them to adhere to epithelial cells and, recently, F11 fimbriae have been identified on many isolates.

\section{E. coli vaccines}

$E$. coli disease in farm animals is an important cause of economic loss and several vaccines are available commercially. Vaccines based on purified fimbrial antigens and toxoids have been shown experimentally to provide good passive protection to neonatal animals against ETEC infections. ${ }^{72}$ For pigs, toxoid VT2e vaccines have been developed for control of oedema disease and PWD. New approaches to disease prevention are being developed, particularly the use of toxoid and fimbrial antigen mixtures administered with novel adjuvants or immunostimulating complexes. Additionally, recombinant DNA technology is being used to develop rationally attenuated live strains and multivalent vectors.

However, it is perhaps salutary to point out that, despite all the advances made in our understanding of $E$. coli as a pathogen, a recent survey of $E$. coli isolates from farm animals in the $\mathrm{UK}^{74}$ demonstrated that the common serotypes and virulence determinants were the same as those recorded 25 years ago.

STAPHYLOCOCCAL AGGRESSINS AND DISEASE-THE LAST 25 YEARS

\section{G. Gemmell}

Department of Bacteriology, University of Glasgow Medical School, Royal Infirmary, Glasgow

Staphylococcus aureus strains may produce various extracellular substances including the enterotoxins (of which there are six serotypes), toxic shock syndrome toxin and exfoliative toxins (of which there are two serotypes) besides the classical haemolysins (of which there are four types), leukocidins and other exoenzymes which may themselves be intrinsically toxic. Much of this information has been garnered in the last 25 years during which time three toxin-mediated disease syndromes have been recognised. This short review provides more details of how $S$. aureus is still showing new aspects to its pathogenicity for man more than 100 years after its discovery by Alexander Ogston.

The first of these new disease syndromes was described by a dermatologist, Lyell, in Glasgow in
1969 as scalded skin syndrome, which usually affects neonates causing a characteristic blistering of the skin. ${ }^{80}$ Phage group II strains of $S$. aureus are most often associated with disease although other phage types can be implicated. It is of interest that the same strain may cause impetigo contagiosa in older siblings indicative of important differences in host response related to age. Clinical characteristics of this syndrome are summarised in table IV.

Soon after its description, several attempts were made to attribute the skin blistering to a biological product of the staphylococcus, and although $\delta$ haemolysin was first implicated, ${ }^{81,82}$ subsequently a new toxin called epidermolytic toxin or exfoliatin was described. ${ }^{83}$ This toxin causes sub-epidermal cleavage $^{84}$ and can reproduce one of the main characteristics of the disease in neonatal mice. ${ }^{83}$ Exposure of skin to exfoliatin results in significant changes at the ultrastructural as well as histological level. Electronmicroscopy has shown that the individual cells of the stratum granulosum are attached to each other by specialised cell membrane thickenings called desmosomes and the spaces between the cells are filled with material containing small translucent bubbles. The toxin causes these bubbles to disappear followed by a widening of the intercellular gap and splitting of the desmosomes forming a cleft between the cell layers. At a molecular level, the toxin is probably a serine protease. It is now clear that there are two serological varieties of exfoliative toxin, one of which, (ETA) is a heat-stable protein of $30 \mathrm{kDa}$ whose synthesis is chromosomally controlled; the other (ETB) has almost the same molecular size but is heat labile and plasmid controlled. Antibodies to both toxins can be detected during convalescence.

Chronologically, the next major development in staphylococcal disease came almost 10 years later with the discovery of large numbers of cases of septic shock with a morbilliform rash, desquamation and multiple organ failure related to use of a particular tampon by young menstruating females in certain parts of the USA. ${ }^{85}$ The Centers for Disease Control has produced diagnostic criteria for toxic shock syndrome (TSS) and these are described in table V. It was significant that these cases occurred initially in Minnesota and Wisconsin since the discovery of a new staphylococcal toxin, named either enterotoxin $\mathrm{F}^{86}$ or pyrogenic toxin, ${ }^{87}$ could be attributed to the presence of two prominent research groups in those two states. The new toxin was shown to cause vomiting in monkeys and structural and serological evidence suggested that it was different from enterotoxins described previously. In contrast, attributes of streptococcal pyrogenic toxin appeared to resemble those of the new toxin and it was felt that the new toxin could be a relative. ${ }^{87}$ After some debate, a consensus view has prevailed recognising the toxin as toxic shock syndrome toxin-1 (TSST-1).

So far only one species of TSST-1 has been described and its biological properties include the capacity to 
Table IV. Features of scalded skin syndrome

Occurs in infants and young children

Very rare in adults

Sudden onset of widespread reddening of skin

Bullae formation

Widespread loss of skin exposing dark red painful surface

Caused by cleavage of middle layers of epidermis

Aetiological agent in toxigenic $S$. aureus mainly belonging to phage group II

Table V. Features of toxic shock syndrome

Usually seen in women during menstruation

No association with particular phage types

Causes multiple clinical symptoms

Symptoms attributable to toxic shock syndrome toxin

Convalescence is not correlated with antibody production

Endotoxin bioactivity is potentiated by toxic shock syndrome

toxin

Syndrome can occur following other staphylococcal infections

induce fever directly or indirectly via cytokines from macrophages, to act as a specific mitogen for $T$ cells, to enhance host susceptibility to endotoxin, to suppress immunoglobulin synthesis and to impair tumour necrosis factor-induced chemotaxis of polymorphonuclear leucocytes. ${ }^{88}$

Although the original outbreak was closely associated with menstruation, non-menstrual TSS has been described almost as frequently in recent years. An analysis of TSS over the period 1985-1991 in England and Wales revealed 103 menstrually associated cases, 26 associated with septicaemia, 43 associated with localised skin infections or burns, 29 cases occurring post-operatively and 11 associated with pneumonia. ${ }^{89}$ These associations have permitted some latitude within the original CDC definition of TSS but have not changed our perception of TSST-1 as an important toxin of $S$. aureus. There has also been an association of enterotoxin A and, to a lesser extent, exterotoxin $\mathrm{B}^{90}$ with TSS. In this connection, it is significant that each of the staphylococcal enterotoxins, TSST-1 and the pyrogenic toxins of Streptococcus pyogenes share some similar properties with each other and now comprise a group of toxins with common structural features and a novel activity as "superantigens". ${ }^{91}$ Such superantigens stimulate populations of $T$ cells expressing particular $\mathrm{T}$-cell receptor $\beta$-chain variable $(\mathrm{V} \beta)$ gene segments ${ }^{92}$ and by so doing possess immunomodulatory activity. The superantigens bond to the MHC class II molecules on the cell surface.

Such bioactivity attributable to a staphylococcal exotoxin has re-awakened interest in another disease syndrome seen in infancy and early childhood called Kawasaki syndrome. This syndrome has clinical features in common with TSS (see table VI) including erythematous induration of the hands and feet, rash and high fever as well as cervical lymphadenopathy. ${ }^{93}$ Although believed to be an infectious disease, no proof was forthcoming and an immunological cause was proposed which included activation of $\mathrm{T}$ cells, monocytes and macrophages. A recent study of 16 patients with Kawasaki syndrome ${ }^{94}$ revealed that toxinogenic bacteria could be isolated from 13 , whereas only in one of 15 control subjects were similar bacteria isolated. In particular, TSST-1-producing $S$. aureus was isolated from 11 of 13 toxin-positive cultures and streptococcal pyrogenic toxins $\mathrm{B}$ and $\mathrm{C}$ from the other two. There is every likelihood that the same toxins associated with TSS and capable of acting as superantigens could be closely implicated in Kawasaki syndrome. The association of Kawasaki syndrome with marked activation of $\mathrm{T}$ cells and monocytes/macrophages is thought to play an important part in the pathogenesis of vascular endothelial cell injury during the acute disease.

Understanding of staphylococcal disease is still unfolding. Coagulase-negative staphylococci (CNS) previously thought to be non-pathogenic are now recognised as significant causes of infections including colonisation of CSF-shunt valves, ${ }^{95}$ prosthetic heart valves and intravascular catheters. ${ }^{96}$ It is now recognised that clinically significant strains are capable of elaborating several of the toxins and enzymes normally produced by $S$. aureus. For example, strains of $S$. epidermidis, $S$. haemolyticus and $S$. intermedius produce a haemolysin similar to the $\delta$-haemolysin of $S$. aureus. ${ }^{97}$ The haemolysin is a protein of $\geqslant 100 \mathrm{kDa}$ with an iso-electric point of 4.25 and is neutralised by specific antiserum and egg yolk lecithin but not by heating to $60^{\circ} \mathrm{C}$. In addition to its haemolytic activity, the toxin was also shown to have some activity against tissue culture cells. Correlation was observed between haemolysis of human erythrocytes and leakage of a radioactive uridine marker from lung fibroblasts. On the basis of these results a diagnostic assay for toxinogenic CNS was developed in which colonies of CNS were grown on soft agar above a monolayer of fibroblasts. Cytotoxin-positive strains were recognised by their ability to damage the underlying tissue culture cells. Good correlation was found between haemolytic activity and cell cytotoxicity. Whether such exoproducts play a part in pathogenesis of infection is still unresolved, ${ }^{98}$ although it is clear that such toxins are produced in vivo because antibodies can be recognised in serum from convalescent patients. The incidence of toxin and aggressin production amongst clinical isolates of coagulase-negative staphylococci is summarised in table VII.

Within the last 10 years there have also been advances in understanding of the predilection of coagulase-negative staphylococci for plastic surfaces. ${ }^{99}$ Initially, an adhesin is involved followed by the biosynthesis of variable amounts of extracellular slime substance (ESS) which comprises a teichoic acidprotein complex. ${ }^{100}$ As well as stabilising microcolonies of the staphylococci on plastic surfaces, ESS is thought to interfere with polymorphonuclear leucocyte function preventing their ingestion and kill- 
Table VI. Features of Kawasaki syndrome

An acute multi-system vasculitis of infancy and early childhood

Fever for 5 days or more

Non-exudative conjunctival infection

Changes in pharynx (mucosal erythema, dry fissured lips,

"strawberry tongue")

Erythema of palms and soles

Swelling of hands and feet

Periungual desquamation

Polymorphous rash

Cervical adenopathy

Table VII. Toxins and enzymes produced by 118 isolates of coagulase-negative staphylococci

\begin{tabular}{|c|c|c|}
\hline \multirow{2}{*}{$\begin{array}{l}\text { Property } \\
\text { measured }\end{array}$} & \multicolumn{2}{|c|}{$\begin{array}{c}\text { Number of strains with indicated } \\
\text { activity isolated from }\end{array}$} \\
\hline & $\begin{array}{l}\text { blood/endocarditis } \\
\text { abscesses and } \\
\text { wounds ( } 42)\end{array}$ & $\begin{array}{l}\text { Urinary tract } \\
\text { infections } \\
(76)\end{array}$ \\
\hline$\alpha$-haemolysin & 27 & 42 \\
\hline$\delta$-haemolysin & 21 & 49 \\
\hline DNAase & 32 & 38 \\
\hline Gelatinase & 27 & 23 \\
\hline Egg yolk factor & 5 & 23 \\
\hline Succinic oxidase factor & 30 & 39 \\
\hline Lipase/esterase & 38 & 57 \\
\hline Phosphatase & 31 & 32 \\
\hline
\end{tabular}

Adapted from Gemmell and Roberts. ${ }^{97}$

ing. ${ }^{101}$ It is likely that such activities are more important in immunocompromised patients and as such their association with disease is much clearer.

Finally, the contribution made by Kapral and colleagues to knowledge of staphylococcal survival in vivo within abscesses should be recognised. A well recognised enzyme with lipolytic and esterolytic activity has been shown to be produced by most strains of $S$. aureus and variably by several species of coagulase-negative staphylococci. ${ }^{102,103}$ The enzyme is capable of attacking saturated fatty acids with 15-18 carbon atoms; such activity can be inhibited by mono, di- and triglycerides. By use of a mouse model to follow the role of this enzyme-called fatty acid modifying enzyme (FAME)--Kapral et al. have shown that higher survival as well as greater multiplication rates in vivo are correlated with production of this enzyme, implying yet another staphylococcal aggressin of importance to its pathogenicity. ${ }^{104}$

This review of the last 25 years of research into staphylococcal pathogenicity has revealed several new facets hitherto undescribed in this common pathogen for man. As more and more about the $S$. aureus genome is discovered, ${ }^{105,106}$ it is unlikely that much more about its virulence characteristics will be discovered, but nothing is certain in medical microbiology.
LISTERIA SPP. AND LISTERIOSIS-25 YEARS ON

\section{A. P. MacGowan}

Department of Medical Microbiology, Southmead Health Services NHS Trust, Westbury-on-Trym, Bristol, BS10 5NB

The first issue of the Journal of Medical Microbiology contained a case report of a Listeria monocytogenes infection in a full-term neonate occurring in Glasgow. This was the first case of its type the authors had found in over 3000 autopsies, conducted over the previous decade. ${ }^{107}$ Although well described in Germany, this type of infection was then unusual in the UK. Nowadays we would have no difficulty in recognising this as one of the typical manifestations of listeriosis, but it remains relatively rare.

L. monocytogenes was first described around 40 years before the first issue of the Journal was published, initially as a pathogen of laboratory animals ${ }^{108}$ and then, a short time later in 1929, it was associated with an infectious mononucleosis-type syndrome in man. ${ }^{109}$ Burn ${ }^{110}$ subsequently reported the infective syndromes we now associated with $L$. monocytogenes-neonatal infection and acute meningitis in adults. Much of the first 40 years of accumulated data on all aspects of listeriosis was summarised by Gray and Killinger ${ }^{109}$ in an excellent review which remains valuable today. Since 1968, our understanding of listeria has advanced in many ways including veterinary infection and pathogenesis and virulence factors; however, in the following sections I will discuss further taxonomy, typing, epidemiology, human clinical infection and antimicrobial chemotherapy.

\section{Taxonomy}

In 1968, there was a single species in the genus Listeria, L. monocytogenes, but three associated species of uncertain taxonomic affiliation were grouped with it-L. murrayi, L. grayi and $L$. denitrificans. In the 1970 s, it was recognised that the various non-haemolytic bio- or serovars of $L$. monocytogenes isolated from environmental sources may represent further species. ${ }^{111}$ In the early $1980 \mathrm{~s}$, on the basis of DNADNA hybridisation studies, strains previously designated L. monocytogenes (sensu lato) were divided into L. monocytogenes (sensu stricto) and closely related species $L$. ivanovii (now containing two subspecies), L. innocua, L. welshimeri and L. seeligeri. ${ }^{112}$ Whole-cell protein electrophoresis, many biochemical tests, antimicrobial sensitivity patterns, peptidoglycan structure and lipoteichoic acids in the cell walls are similar for the five major species. ${ }^{113-116}$ However, other tests may be useful in discriminating between species, including conventional biochemical tests, haemolysis, susceptibility to the antimicrobial agent fosfomycin, animal virulence and DNA typing. ${ }^{117-120}$ The classification is especially useful medically because different species have different infective potential for man. $L$. monocytogenes is the main pathogen of man accounting for $>99 \%$ of all infections and also causes disease in animals $;{ }^{121} L$. ivanovii causes infection in sheep but 
accounts for $<1$ in 1000 infections in man and $L$. seeligeri has been isolated from only a single case of human acute meningitis. ${ }^{122} L$. welshimeri and $L$. innocua have not been associated with human infection so far. In the environment, most food isolates are mainly $L$. monocytogenes or $L$. innocua but $L$. ivanovii may be isolated from mutton. In human faeces and sewage, $L$. monocytogenes and $L$. innocua predominate, and in a recent study, $L$. ivanovii and $L$. seeligeri were common in soil (MacGowan, unpublished data). Hence, in the study of the epidemiology of human infection and its relation to food or other environmental reservoirs, most attention should be paid to the identification and typing of $L$. monocytogenes.

\section{Typing of L. monocytogenes}

Serotyping was first described by Paterson ${ }^{123}$ and extended and developed up to the late 1970s by Donker-Voet and Seeliger (see Seeliger and Hohne ${ }^{124}$ ). It is based on a number of $\mathrm{O}$ and $\mathrm{H}$ antigens and Listeria spp. can be divided into more than 10 serovars. Biotyping was the only other typing method available 25 years ago but it has not stood the test of time. ${ }^{125} \mathrm{In}$ the mid 1990s, the range of typing methods has increased greatly and so has their importance. Bacteriophage typing was developed in the 1970s and several molecular typing methods such as random amplified pleomorphic DNA (RAPD)-PCR typing and multilocus enzyme electrophoresis have become established. ${ }^{120,126,127}$ In the interim, several other typing methods were tried with varying successresistogram, endonuclear restriction pattern, monocine, plasmid and DNA probe-based typing systems. ${ }^{119,128-131}$ None of these has gained widespread acceptance and listeria typing laboratories require a range of typing technologies because serotyping and bacteriophage typing have problems in terms of discrimination and typability. Serotyping suffers from poor discrimination; $95 \%$ of clinical isolates of $L$. monocytogenes fall into four main groups and $60 \%$ of human isolates in the UK are serovar $4 \mathrm{~b} .{ }^{121} \mathrm{Bac}-$ teriophage typing requires a set of 25-30 lytic phages and, in the UK, $82 \%$ of serovar $4 \mathrm{~b}$ but only $37 \%$ of serovar $1 / 2$ are typable. Phage typing is both reproducible and discriminatory for those strains which are typable. ${ }^{132}$ As a significant number of strains cannot be phage typed, there is a need for a third method. RAPD-PCR typing has the potential to fill this gap as it is characterised by good typability, is easy to perform and requires minimal investment in equipment, but reproducibility is difficult, no standard primers for typing are established and it is not suitable for typing large numbers of isolates ${ }^{120}$ (MacGowan, unpublished data). Adequate typing methods need to be certralised in a limited number of Listeria reference laboratories across the European Union if the incidence of infection is to be monitored and clusters of cases due to L. monocytogenes are to be identified rapidly and investigated. It is hoped that, by such a process of active surveillance, the large outbreaks of infection which have been such a feature of listerosis in the last 25 years can be prevented. ${ }^{133}$

\section{Epidemiology of human infection}

There are very few totally reliable studies of the incidence of listeriosis in Europe and North America because data are usually collected by national reference laboratories and are, therefore, always incomplete even in countries where listeriosis is notifiable. ${ }^{134-136}$ The incidence of infection in the UK since 1967 is shown on table VIII. An ongoing collection of data on clinical cases in Bristol since 1983 has indicated that, when local data are compared to national reporting, around a quarter to one-third of cases are not registered centrally. However, it is clear that the incidence of infection has increased since the 1960s and there was a peak between 1986 and 1989 which was associated with consumption of a specific type of pâté. ${ }^{137}$ The recognition that the outbreaks of listeriosis, which had been documented since the 1950s, were associated with consumption of contaminated foodstuffs radically changed our understanding of the epidemiology of human disease. ${ }^{138}$ This changed understanding also extended to several other areas (table IX), such as the discovery that neonates may transmit infection to other neonates in the hospital environment (reviewed by Schlech ${ }^{133}$ ). Since the first association of epidemic listeriosis with coleslaw contaminated on a farm, ${ }^{138}$ it has become clear that farming practice, food preparation and distribution are all important in contributing to outbreaks which have occurred regularly throughout the 1980s and have been associated with fresh cream, pasteurised milk, ${ }^{139}$ fruit, Mexican-style cheese, soft cheese ${ }^{140}$ and ice cream, salami or Brie cheese. ${ }^{141}$ Sporadic cases of infection have also been associated epidemiologically with consumption of undercooked chicken or hot dogs and individual case histories have been reported that suggest linkages to some foods. ${ }^{142-145}$ These individual cases give rise to some problems in interpretation because the incubation period for human infection may be up to 90 days and it is not possible to exclude contamination of food by the infected human patient, hence they should be treated with caution. However, bacteriological monitoring of foodstuffs and updating of advice to the general public on the risks of listeriosis are likely to be important in preventing disease in the future. The isolation rates and number of Listeria spp. found in food such as pâté and soft cheese has declined recently. ${ }^{146-148}$ In contrast, isolation rates remain unchanged in raw meats, chicken, sausages and cookchill foods, ${ }^{147-149}$ but the numbers of bacteria per gram of food may now have declined.

\section{Clinical aspects of human infection}

In the last 25 years, the main clinical syndromes of $L$. monocytogenes infection have changed and expanded. In 1968, the major infections were acute 
Table VIII. The incidence of listeriosis in the UK 1967-1993

\begin{tabular}{lll}
\hline \multicolumn{1}{c}{ Population } & Period & $\begin{array}{c}\text { Infections } / 10^{5} \text { population/ } \\
\text { year }\end{array}$ \\
\hline England and Wales & 1967 & $0 \cdot 02$ \\
& 1985 & $0 \cdot 30$ \\
& 1988 & $0 \cdot 58$ \\
Bristol & $1990-1993$ & $0 \cdot 22$ \\
Scotland & $1983-1993$ & $0 \cdot 35$ \\
& $1977-1986$ & $0 \cdot 14$ \\
& 1987 & $0 \cdot 52$ \\
\hline
\end{tabular}

meningitis - usually in adults - and disseminated infection (granulomatosis infantiseptica) in neonates. ${ }^{107.150}$ Now a more detailed picture is available (table X) with neonatal infection being divided into an early disseminated type and late infection, usually meningitis. In adults, it is now recognised that a wide range of infections can occur in immunocompromised patients; however, bacteraemia or CNS infection remain the commonest manifestations. ${ }^{151}$ Within these common syndromes, all of which require laboratory diagnosis, infection related to pregnancy has declined relative to other forms of infection, especially in the last 5 years $;^{152,153}$ and bacteraemia, a disease of immunocompromised adults is becoming increasingly important. For example, in Sweden between 1958 and $1974,16 \%$ of adult cases presented as bacteraemia; this had increased to $25 \%$ in a review conducted between 1968 and 1978 and was $42 \%$ in a collection of cases between 1967 and 1985. ${ }^{153-155}$ In Bristol, data collected in the last decade indicate that $63 \%$ of adult cases now present as bacteraemia (MacGowan, unpublished data). As the importance of bacteraemia has increased, the relative importance of CNS infection has declined but encephalitis and abscess formation have become recognised increasingly. ${ }^{156}$ In addition to the risk groups for infection known in the 1960s, renal transplantation, ${ }^{157}$ malignancy, steroid therapy, diabetes mellitus, collagen vascular diseases and HIV infection have been added. ${ }^{155,158.159}$ However, some
Table X. The clinical syndromes of listeriosis

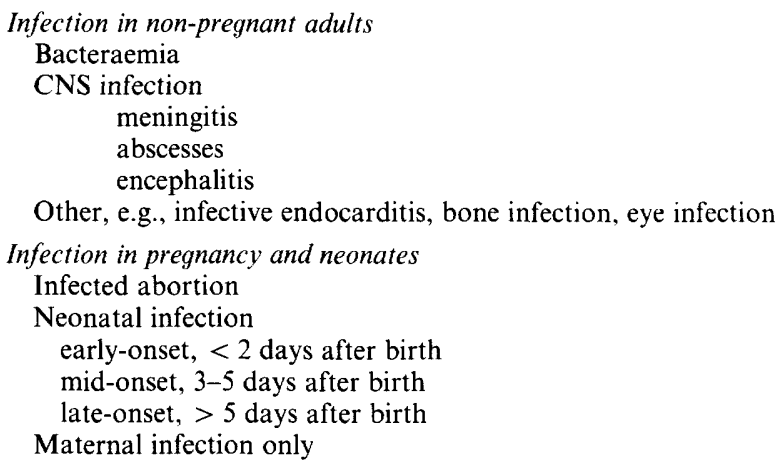

patients have no obvious predisposing factors including $30-40 \%$ of patients with meningitis and $10 \%$ with primary bacteraemia. ${ }^{155,156,160}$ The mortality has remained high with $50 \%$ being reported in neonates ${ }^{151}$ and $44 \%$ in adults. ${ }^{153}$ However, poor prognostic factors for acute meningitis are now recognised, such as age $>50$ years, pre-existing disease, convulsions, requirement for renal or inotropic support, coma, focal neurological signs, low platelet count, raised serum creatinine and inadequate antimicrobial chemotherapy ${ }^{155,156}$ (MacGowan, unpublished data). These may help in deciding which cases need aggressive supportive therapy and optimal antimicrobial treatment.

\section{Antimicrobial chemotherapy}

The mainstays of therapy in the 1960 s were penicillin, chloramphenicol and streptomycin. Sulphonamides and tetracycline were also used occasionally but it is unclear how effective they were. Ampicillin was used from 1968 onwards ${ }^{161}$ and was shown to be superior to penicillin in a comparative clinical trial in $1971 ;^{162}$ however, this study has been questioned and it is now thought that penicillin and ampicillin are

Table IX. Changes in the understanding of the epidemiology of listeriosis since 1968

\begin{tabular}{|c|c|c|}
\hline Epidemiological feature & 1968 & 1993 \\
\hline Pattern of infection & $\begin{array}{l}\text { Poorly defined-sporadic and } \\
\text { outbreaks }\end{array}$ & $\begin{array}{l}\text { Well defined - sporadic and } \\
\text { outbreaks }\end{array}$ \\
\hline Seasonality & Not known & Yes \\
\hline Sex differences & Not known & $\begin{array}{l}\text { Elderly male } \\
\text { Pregnant female }\end{array}$ \\
\hline Location & Possibly rural & Mainly urban \\
\hline \multicolumn{3}{|l|}{ Occurrence in } \\
\hline food & Yes & Yes \\
\hline soil & Not known & Yes \\
\hline sewage & Not known & Yes \\
\hline Human carriage & Yes & Yes \\
\hline \multicolumn{3}{|l|}{ Routes of transmission } \\
\hline food & Proposed & Yes \\
\hline animal contact & Yes & Yes but rare \\
\hline venereal & Yes & No \\
\hline fomites & Not known & Yes \\
\hline
\end{tabular}


equivalent agents. ${ }^{155,156,163,164}$ Combination therapy has been common, but ampicillin and gentamicin, the most commonly used clinical combination, were shown to be synergic in vitro only in $1972 . .^{165}$ Subsequently, many combinations have been tested in the laboratory ${ }^{166}$ but none has been shown to be beneficial clinically. Recently, multiresistant strains of L. monocytogenes have been described in France, ${ }^{167}$ but such strains have not been isolated in the UK where only tetracycline resistance occurs at a frequency of about $1-2 \%{ }^{168}$ Laboratory studies have also shown that Listeria spp. are resistant to cephalosporins but that co-trimoxazole is a bactericidal combination. ${ }^{166}$ Case reports indicate that infections respond poorly to cephalosporins but reasonably well to co-trimoxazole; however, no comparative data are available. ${ }^{169}$ Only the antimicrobial therapy of acute meningitis has been studied in any depth and the results seem to indicate that mortality can be reduced from $30 \%$ to $10-15 \%$ by the use of penicillin or ampicillin at doses of $>6 \mathrm{~g} /$ day. ${ }^{155}$ The addition of an aminoglycoside to ampicillin is not of proven clinical benefit, ${ }^{155,156,170}$ and runs the well known risks of aminoglycoside toxicity. However, ampicillin concentrations in the CSF would not exceed the MBC for $L$. monocytogenes measured in the laboratory even when given in large doses, indicating that further studies are required. ${ }^{171}$ Chloramphenicol has now fallen out of favour as it has been associated with high relapse and mortality rates and the need to change therapy to alternative agents during therapy. ${ }^{155,170,172,173}$ In con-

\section{References}

1. Turk DC, May JR. Haemophilus influenzae: its clinical importance. London, English Universities Press. 1967.

2. Turk DC, Holdaway MD. Capsulated Haemophilus influenzae and bronchiectasis. J Med Microbiol 1968; 1 : 79-88.

3. Moxon ER, Kroll JS. The role of bacterial polysaccharide capsules as virulence factors. Curr Top Microbiol Immunol 1990; 150: $65-86$.

4. Kroll JS, Hopkins I, Moxon ER. Capsule loss in H. influenzae type $b$ occurs by recombination-mediated disruption of a gene essential for polysaccharide export. Cell $1988 ; 53$ : 347-356.

5. Barbour ML, Crook DW, Mayon-White RT. An improved antiserum agar method for detecting carriage of Haemophilus influenzae type b. Eur J Clin Microbiol Infect Dis $1993 ; 12$ : 215-217.

6. Kroll JS, Zamze S. Loynds B, Moxon ER. Common organization of chromosomal loci for production of different capsular polysaccharides in Haemophilus influenzae. J Bacteriol 1989; 171: 3343-47.

7. Falla TJ. Molecular epidemiology of Haemophilus influenzae. PhD Thesis, University of Wales, 1993.

8. Kroll JS, Loynds BM, Moxon ER. The Haemophilus influenzae capsulation gene cluster: a compound transposon. $\mathrm{Mol}$ Microbiol 1991; 5: 1549-1560.

9. van-Ketel RJ, de Wever B, van Alphen L. Detection of Haemophilus influenzae in cerebrospinal fluids by polymerase chain reaction DNA amplification. $J$ Med Microbiol 1990; 33: 271-276.

10. Pennington TH. Haemophilus species and clones. Rev Med Microbiol 1993; 4: 50-58.

11. Jordens JZ, Leaves NI, Anderson EC, Slack MP. Polymerase chain reaction-based strain characterization of noncapsulate Haemophilus influenzae. J Clin Microbiol 1993; 31: $2981-2987$. trast, a comparative study of chloramphenicol plus gentamicin and ampicillin plus gentamicin in the treatment of meningitis showed both treatments to be equivalent, but numbers were small. ${ }^{174}$ While it is difficult to be dogmatic, most patients with listeriosis should be treated with adequate doses of ampicillin, perhaps with an added aminoglycoside depending on the clinical status. Patients allergic to penicillins can be treated with glycopeptides for non-CNS infections or co-trimoxazole for infection in any site. Chloramphenicol plus an aminoglycoside may be of use in treating penicillin-allergic patients with acute meningitis.

\section{The future}

Prevention of listeriosis remains preferable to attempted cure as mortality is still considerable. This can be achieved by continued attention to food preparation, distribution and storage practices, periodic surveys of food-stuffs to identify foods of especial risk, and subsequent re-enforcement of advice on risk reduction such as adequate cooking of raw meats and avoidance of some foods. This approach should be combined with central epidemiological monitoring of the infection with supporting typing methods for early detection of case clusters and prompt investigation of potential outbreaks. Once patients have contracted infection there is evidence that treatment with large doses of penicillin or ampicillin as mono-therapy may reduce mortality.

12. Falla TJ, Dobson SRM, Crook DWM et al. Population-based study of non-typable Haemophilus influenzae invasive disease in children and neonates. Lancet 1993; 341 : 851-854.

13. Slack MPE, Crook DWM, Jordens JZ et al. Molecular and epidemiological aspects of Haemophilus influenzae infection. PHLS Microbiol Dig 1993; 10: 122-128.

14. Hansman D. The epidemiology of invasive Haemophilus influenzae infections in children under five years of age in the Northern Territory: a three year study. Med J Aust 1990; 153: 115-116.

15. Lehmann D. Epidemiology of acute respiratory tract infections, especially those due to Haemophilus influenzae, in Papua New Guinean children. J Infect Dis 1992; 165 Suppl 1: S20-S25.

16. Green BA, Vazquez ME, Zlotnick GW et al. Evaluation of mixtures of purified Haemophilus influenzae outer membrane proteins in protection against challenge with nontypeable $H$. influenzae in the chinchilla otitis media model. Infect Immun 1993; 61: 1950-1957.

17. Holt LB, Spasojevíc V. The role of surface antigens in the protective potency of Bordetella pertussis suspensions as measured by the intracerebral challenge technique in mice. J Med Microbiol 1968; 1: 119-126.

18. Wardlaw AC, Hall E, Parton R. Coughing rat model of pertussis. Biologicals 1993; 21: 27-29.

19. Hall E, Parton R, Wardlaw AC. Cough production, leukocytosis and serology of rats infected intrabronchially with Bordetella pertussis. J Med Microbiol 1994; 40: 205-213.

20. Parton R, Hall E, Wardlaw AC. Responses to Bordetello pertussis mutant strains and to vaccination in the coughing rat model of pertussis. $J$ Med Microbiol 1994: 40: $307-312$.

21. Miller E. Current epidemiology of pertussis in the U.K Biologicals 1993; 21: 10-11.

22. Fine PEM. Epidemiological considerations for whooping 
cough eradication. In: Wardlaw AC, Parton R (eds) Pathogenesis and immunity in pertussis. Chichester Wiley. 1988: 451-467.

23. Cherry JD, Brunell PA, Golden GS, Karzon DT. Report of the task force on pertussis and pertussis immunization-1988. Pediatrics 1988; 81 Suppl: 939-984.

24. Marcuse EK, Wentz KR. The NCES reconsidered: summary of a 1989 workshop. National Childhood Encephalopathy Study. Vaccine 1990; 8: 531-535.

25. Cowan LD, Griffin MR, Howson CP et al. Acute encephalopathy and chronic neurological damage after pertussis vaccine. Vaccine 1993; 11: 1371-1379.

26. Communicable Diseases and Environmental Health in Scotland Weekly Report 1993; 27: No. 93/46, p. 1-2.

27. Muller AS, Leeuwenburg J, Pratt DS. Pertussis: epidemiology and control. Bull WHO 1986; 64: 321-331.

28. Sato Y, Sato H. Animal models of pertussis. In: Wardlaw AC, Parton R (eds) Pathogenesis and immunity in pertussis. Chichester, Wiley. 1988: 309-325.

29. Wardlaw AC. Multiple discontinuity as a remarkable feature of the development of acellular pertussis vaccines. Vaccine 1992; 10: 643-651.

30. Weiss AA, Falkow $S$. The use of molecular techniques to study microbial determinants of pathogenicity. Philos Trans $R$ Soc Lond [Biol] $1983 ; 303: 219-255$.

31. Ui M. The multiple biological activities of pertussis toxin. Furman BL, Sidney FM, Smith M. Metabolic disturbances produced by pertussis toxin. Munoz JJ. Action of pertussigen (pertussis toxin) on the host immune system. In: Wardlaw AC, Parton R (eds) Pathogenesis and immunity in pertussis. Chichester, Wiley. 1988: $121-145 ; 147-172 ; 173-192$

32. Parton $R$. Changing perspectives on pertussis and pertussis vaccination. Rev Med Microbiol 1991; 2: 121-128.

33. Burns DL. Subunit structure and enzymic activity of pertussis toxin. Microbiol Sci $1988 ; 5: 285-287$.

34. Locht C, Keith JM. Pertussis toxin gene: nucleotide sequence and genetic organization. Science 1986; 232: 1258-1264.

35. Nicosia A, Perugini M, Franzini $\mathrm{C}$ et al. Cloning and sequencing of the pertussis toxin genes: operon structure and gene duplication. Proc Natl Acad Sci USA 1986;83 $4631-4635$.

36. Rappuoli R, Pizza M, Podda A, de Magistris MT, Nencioni L. Towards third-generation whooping cough vaccines. Tibtech 1991; 9: 232-238.

37. Hewlett EL, Cherry JD. New and improved vaccines against pertussis. In: Woodrow GC, Levine MM (eds) New generation vaccines. New York, Marcel Dekker. 1990: 231-250.

38. Sato $Y$, Kimura M, Fukumi $H$. Development of a pertussis component vaccine in Japan. Lancet 1984; 1 : 122-126.

39. Ad hoc group for the study of pertussis vaccines. Placebocontrolled trial of two acellular pertussis vaccines in Sweden--protective efficacy and adverse events. Lancet 1988; 1 : 955-960.

40. Coote JG. Antigenic switching and pathogenicity: environmental effects on virulence gene expression in Bordetella pertussis. J Gen Microbiol 1991; 137: 2493-2503.

41. Preston NW. Pertussis today. In: Wardlaw AC, Parton R (eds) Pathogenesis and immunity in pertussis. Chichester, Wiley. 1988: 1-18

42. Friedman RL, Nordensson K, Wilson L, Akporiage ET, Yocum DE. Uptake and intracellular survival of Bordetella pertussis in human macrophages. Infect Immun 1992; 60: 4578-4585.

43. Porter JF, Connor K, Donachie W. Isolation and characterization of Bordetella parapertussis-like bacteria from ovine lungs. Microbiology 1994; 140: 255-261.

44. Porter JF, Parton R, Wardlaw AC. Growth and survival of Bordetella bronchiseptica in natural waters and in buffered saline without added nutrients. Appl Environ Microbiol 1991; 57: 1202-1206.

45. Hornibrook JW, Ashburn LL. A study of experimental pertussis in the young rat. Public Health Rep 1939; 54 $439-444$.

46. Woods DE, Franklin R, Cryz SJ, Gauss M, Peppler M, Ewanowich C. Development of a rat model for respiratory infection with Bordetella pertussis. Infect Immun 1989; 57 $1018-1024$
47. Pittman M. Pertussis toxin: the cause of the harmful effects and prolonged immunity of whooping cough. A hypothesis. Rev Infect Dis 1979; 1: 401-412.

48. Smith HW, Linggood MA. Observation on the pathogenic properties of the K88, Hly and Ent plasmids of Escherichia coli with particular reference to porcine diarrhoea. J Med Microbiol 1971; 141: 467-485.

49. Pickett CL, Twiddy EM, Belisle BW, Holmes RK. Cloning of genes that encode a new heat-labile enterotoxin of Escherichia coli. J Bacteriol 1986; 165: 348-352.

50. Harnett NM, Gyles CL. Enterotoxin plasmids in bovine and porcine enterotoxigenic Escherichia coli of $O$ groups 9, 20, 64 and 101. Can J Comp Med 1985; 49: 79-87.

51. Konowalchuk J, Speirs JI, Stavric S. Vero response to a cytotoxin of Escherichia coli. Infect Immun 1977; 18: 775-779.

52. Smith HW, Green P, Parsell Z. Vero cell toxins in Escherichia coli and related bacteria: transfer by phage and conjugation and toxic action in laboratory animals, chickens and pigs. J Gen Microbiol 1983; 129: 3121-3137.

53. Gannon VP, Gyles CL, Wilcock BP. Effects of Escherichia coli Shiga-like toxins (verotoxins) in pigs. Can J Vet Res 1989; 53: 306-312.

54. Caprioli A, Falbo V, Roda LG, Ruggeri FM, Zona C. Partial purification and characterization of an Escherichia coli toxic factor that induces morphological cell alterations. Infect Immun 1983; 39: 1300-1306.

55. Holland RE. Some infectious causes of diarrhea in young farm animals. Clin Microbiol Rev 1990; 3: 345-375.

56. De Rycke J, Gonzales EA, Blanco J, Oswald E, Blanco M, Boivin R. Evidence for two types of cytotoxic necrotising factor in human and animal clinical isolates of Escherichia coli. J Clin Microbiol 1990; 28: 694-699.

57. Falbo V, Famiglietti M, Carpioli A. Gene block encoding production of cytotoxic necrotising factor 1 and hemolysin in Escherichia coli isolates from extraintestinal infections. Infect Immun 1992; 60: 2182-2187.

58. Smith HW. A search for transmissible pathogenic characters in invasive strains of Escherichia coli: the discovery of a plasmid-controlled toxin and a plasmid-controlled lethal character closely associated or identical with colicine V. $J$ Gen Microbiol 1974; 83: 95-111.

59. Moon HW. Colonisation factor antigens of enterotoxigenic Escherichia coli in animals. Curr Top Microbiol Immunol $1990 ; 151: 147-165$.

60. Yano T, Leite DdaS, de Carmargo IJB, Pestano de Castro AF. A probable new adhesive factor (F42) produced by enterotoxigenic Escherichia coli isolated from pigs. Microbiol Immunol 1986; 30: 495-508.

61. Girardeau J-P, Dubourguier HC, Contrepois M. Attachement des $E$. coli enteropathogènes à la muqueuse intestinale Bull. GTV 1980; 4B: 190:49

62. Bertschinger HU, Bachmann M, Mettler C et al. Adhesive fimbriae produced in vivo by Escherichia coli O139:K12 (B): $\mathrm{H} 1$ associated with enterotoxaemia in pigs. Vet Microbiol 1990; 25: 267-281.

63. Fairbrother JM, Lariviere S, Lallier R. New fimbrial antigen F165 from Escherichia coli serogroup 0115 strains isolated from piglets with diarrhea. Infect Immun 1986; 51: $10-15$.

64. Girardeau JP, Der Vartanian M, Ollier JL, Contrepois M. CS31A, a new K88-related fimbrial antigen on bovine enterotoxigenic and septicemic Escherichia coli strains. Infect Immun 1988; 56: 2180-2188.

65. Aning KG, Thomlinson JR, Wray C, Sojka WJ, Coulter J. Adhesion factor distinct from K88, K99, F41, 987P, CFAI and CFAII in porcine Escherichia coli. Vet Rec $1983 ; 112: 251$.

66. Salajka E, Salajkova Z, Alexa P, Hornich M. Colonisation factor different from K88, K99, F41 and 987P in enterotoxigenic Escherichia coli strains isolated from postweaning diarrhea in pigs. Vet Microbiol 1992: 32: $163-175$.

67. Varga J. Characterization of a new fimbrial antigen present in Escherichia coli strains isolated from calves. Zentralbl Veterinarmed B 1991; 38: 689-700.

68. van den Bosch JF, Hendriks JH, Gladigau I, Willems HM, Storm PK, de Graaf FK. Identification of F1l fimbriae on chicken Escherichia coli strains. Infect Immun 1993; 61: 800-806. 
69. Sellwood R, Gibbons RA, Jones GW, Rutter JM. Adhesion of enteropathogenic Escherichia coli to pig intestinal brush borders: the existence of two pig phenotypes $J$ Med Microbiol 1975; 8: 405-411.

70. Bertschinger HU, Stamm M, Vogeli P. Inheritance of resistance to oedema disease in the pig: experiments with an Escherichia coli strain expressing fimbriae 107. Vet Microbiol 1993; 35: 79-89.

71. Olsen A, Jonsson A, Normak S., Fibronectin binding mediated by a novel class of surface organelles on Escherichia coli. Nature 1989; 338: 652-655.

72. Wray C, Morris JA. Aspects of colibacillosis in farm animals J Hyg 1985; 95: 577-593.

73. Tesh VL, O'Brien AD. Adherence and colonization mechanisms of enteropathogenic and enterohemorrhagic Escherichia coli. Microb Pathog 1992; 12: 245-254.

74. Wray C, McLaren IM, Carroll PJ. Escherichia coli isolated from farm animals in England and Wales between 1986 and 1991. Vet Rec 1993; 133: 439-442.

75. Tokhi AM, Peiris JS, Scotland SM, Willshaw GA, Smith HR, Cheasty T. A longitudinal study of Vero cytotoxin producing Escherichia coli in cattle calves in Sri Lanka. Epidemiol Infect 1993; 110: 197-208.

76. Mainil JG, Jacquemin ER, Kaeckenbeeck AE, Pohl PH. Association between the effacing (eae) gene and the Shigalike toxin-encoding genes in Escherichia coli isolates from cattle. Am J Vet Res 1993; 54: 1064-1068.

77. Karmali MA. Infection by verocytotoxin-producing Escherichia coli. Clin Microbiol Rev 1989; 2: 15-38.

78. Chapman PA, Wright DJ, Norman P. Verotoxin-producing Escherichia coli infections in Sheffield: cattle as a possible source. Epidemiol Infect 1989; 102: 439-445.

79. Synge BA, Hopkins GF. Verotoxigenic Escherichia coli $\mathrm{O} 157$ in Scottish calves. Vet Rec 1992; 130: 583.

80. Lyell A, Dick HM, Alexander J O'D. Outbreak of toxic epidermal necrolysis associated with staphylococci. Lancet $1969 ; 1$ : 787-789.

81. Arbuthnott JP, Gemmell CG, Kent J, Lyell A. Haemolysin and enzyme patterns of coagulase-positive staphylococci isolated from toxic epidermal necrolysis, Ritter's disease and impetigo contagiosa. J Med Microbiol 1969; 2: $479-487$

82. Arbuthnott JP, Kent J, Lyell A, Gemmell CG. Toxic epidermal necrolysis produced by an extracellular product of Staphylococcus aureus. B J Dermatol 1971; 85: 145-149.

83. Melish ME, Glasgow LA. The staphylococcal scalded skin syndrome: development of an experimental model. New Engl J Med 1970; 282: 1114-1119.

84. Lillibridge CG, Melish ME, Glasgow LA. Site of action of exfoliative toxin in the staphylococcal scalded-skin syndrome. Pediatrics 1972; 50: 728-738.

85. Shands KN, Schmid GP, Dan BB et al. Toxic-shock syndrome in menstruating women. $N$ Engl J Med 1980; 303: 1436-1442.

86. Bergdoll MS, Crass BA, Reiser RF, Robbins RN, Davis JP. A new staphylococcal enterotoxin, enterotoxin $F$, associated with toxic-shock-syndrome Staphylococcus aureus isolates. Lancet 1981; 1: 1017-1021.

87. Schlievert PM, Shands KN, Dan BB, Schmid GP, Nishimura RD. Identification and characterization of an exotoxin from Staphylococcus aureus associated with toxic shock syndrome. J Infect Dis 1981; 143: 509-516.

88. Arbuthnott JP, Coleman DC, de Azavedo JS. Staphylococcal toxins in human disease. Soc Appl Bacteriol Symp 1990; 19: 101S-107S.

89. Marples RR, Wieneke AA. Enterotoxins and toxic shock syndrome toxin-1 in non-enteric staphylococcal disease. Epidemiol Infect 1993; 110: 477-488.

90. Schlievert PM. Staphylococcal enterotoxin B and toxic-shock syndrome toxin-1 are significantly associated with nonmenstrual TSS. Lancet 1986; 1: 1149-1150.

91. Marrack P, Kappler J. The staphylococcal enterotoxins and their relatives. Science $1990 ; \mathbf{2 4 8}: 705-711$

92. Drake CG, Kotzin BL. Superantigens: biology, immunology, and potential role in disease. J Clin Immunol 1992; 12: 149-162.

93. Leung DYM. Kawasaki disease. Curr Opin Rheumatol 1993; 5: $41-50$

94. Leung DYM, Meissner HC, Fulton DR, Murray DL, Kotzin BL, Schlievert PM. Toxic shock syndrome toxin-secreting
Staphylococcus aureus in Kawasaki syndrome. Lancet 1993; 342: 1385-1388

95. Bayston R. Serological investigations in children with colonized Spitz-Holter valves. J Clin Pathol 1972; 25: 718-720.

96. Winston DJ, Dudnick DV, Chapin M, Ho WG, Gale RP, Martin WJ. Coagulase-negative staphylococcal bacteremia in patients receiving immunosuppressive therapy. Arch Intern Med 1983; 143: 32-36.

97. Gemmell CG, Roberts E. Toxins and enzymes of coagulasenegative staphylococci isolated from human infections. $J$ Hyg Epidemiol Microbiol Immunol 1974; 18: 276-280.

98. Gemmell CG, Thelestam M. Toxinogenicity of clinical isolates of coagulase-negative staphylococci towards various animal cells. Acta Pathol Microbiol Scand Sect B 1981; 89: 417-421.

99. Christensen GD, Simpson WA, Bisno AL, Beachey EH. Adherence of slime-producing strains of Staphylococcus epidermidis to smooth surfaces. Infect Immun 1982; 37: 318-326.

100. Hussain M, Hastings JGM, White PJ. Comparison of cell wall teichoic acid with high molecular weight extracellular slime material from Staphylococcus epidermidis. $J$ Med Microbiol 1992; 37: 368-375.

101. Gray ED, Peters G, Verstegen M, Regelmann WE. Effect of extracellular slime substance from Staphylococcus epidermidis on the human cellular immune response. Lancet 1984; $1: 365-367$.

102. Long JP, Hart J, Albers W, Kapral FA. The production of fatty acid modifying enzyme (FAME) and lipase by various staphylococcal species. J Med Microbiol 1992;37: 232-234.

103. Mortensen JE, Shryock TR, Kapral FA. Modification of bactericidal fatty acids by an enzyme of Staphylococcus aureus. J Med Microbiol 1992; 36: 293-298.

104. Kapral FA, Smith S, Lal D. The esterification of fatty acids by Staphylococcus aureus fatty acid modifying enzyme (FAME) and its inhibition by glycerides. J Med Microbiol 1992; 37: 235-237

105. Musser JM, Schlievert PM, Chow AW et al. A single clone of Staphylococcus aureus causes the majority of cases of toxic shock syndrome. Proc Natl Acad Sci USA 1990;87: 225-229.

106. Foster TJ. The use of mutants for defining the role of virulence factors in vivo. In: Hormaeche CE, Penn CW, Smyth CJ (eds) Molecular biology of bacterial infection: current status and future perspectives. Soc Gen Microbiol Sym 49 1992: 173-191.

107. Scott JM, Henderson A. A case of listeriosis of the newborn. $J$ Med Microbiol 1968; 1: 97-104.

108. Murray EGD, Webb RA, Swann MBR. A disease of rabbits characterised by a large mononuclear leucocytosis, caused by a hitherto underscribed bacillus Bacterium monocytogenes. J Pathol Bacteriol 1926; 29 : 407-439.

109. Gray ML, Killinger AH. Listeria monocytogenes and listeric infections Bacteriol Rev 1966; 30: 309-382.

110. Burn CG. Clinical and pathological features of an infection caused by a new pathogen of the genus Listerella. Am J Pathol 1936; 12: 341-348.

111. Weis J, Seeliger HPR. Incidence of Listeria monocytogenes in nature. Appl Microbiol 1975; 30: 29-32.

112. Rocourt J, Grimont F, Grimont PAD, Seeliger HPR. DNA relatedness among serovars of Listeria monocytogenes sensu lato. Curr Microbiol 1982; 7: 383-388.

113. Rocourt J, Catimel B. Caracterisation biochimique des especes du genre Listeria. Zentralbl Bakteriol Mikrobiol Hyg A 1985; 260: 221-231.

114. Jones D, Feresu S, Collins MD. Classification and identification of Listeria, Brochothrix and Erysiplothrix. In: Courtieu AL, Espaze EP, Reynaud AE (eds) Listeriose, Listeria, Listeriosis. Nantes, Université de Nantes. 1986.

115. Lamont RJ, Petrie DT, Melvin WT, Postlethwaite R. An investigation of taxonomy of Listeria species by comparison of electrophoretic protein patterns. In: Courtieu AL, Espaze EP, Reynaud AE (eds) Listeriose, Listeria Listeriosis. Nantes, Université de Nantes. 1986.

116. Fiedler F. Biochemistry of the cell surface of Listeria strains: a locating general view. Infection 1988; 16 Suppl 2: S92-S97.

117. Schrettenbrunner A, Schroter G, Rocourt J. Antibiotic sus- 
ceptibility of the genus Listeria. In: Courtieu AL, Espaze EP, Reynaud AE (eds) Listeriose, Listeria, Listeriosis. Nantes, Université de Nantes. 1986.

118. Mainou-Fowler T, MacGowan AP, Postlethwaite R. Virulence of Listeria spp: course of infection in resistant and susceptible mice. J Med Microbiol 1988; 27: 131-140.

119. MacGowan AP, Holt HA, Bywater MJ, Reeves DS. In vitro antimicrobial susceptibility of Listeria monocytogenes isolated in the UK and other Listeria species. Eur J Clin Microbiol Infect Dis 1990; 9: 767-770.

120. MacGowan AP, O'Donaghue K, Nicholls S, McLauchlin J, Bennet PM, Reeves DS. Typing of Listeria spp. by random amplified polymorphic DNA (RAPD) analysis. $J$ Med Microbiol 1993; 38: 322-327.

121. McLauchlin J. Listeria monocytogenes, recent advances in the taxonomy and epidemiology of listeriosis in humans. $J$ Appl Bacteriol 1987; 63: 1-11.

122. Rocourt J, Hof H, Schrettenbrunner A, Malinverni R, Bille J Meningite purulente aigue a Listeria seeligeri chez un adulte immunocompetent. Schweiz Med Wochenschr 1986; 116: 248-251.

123. Paterson JS. Flagellar antigens of organisms of the genus Listerella. J Pathol Bacteriol 1939; 48: 25-32.

124. Seeliger HPR, Höhne K. Serotyping of Listeria monocytogenes and related species. In: Bergan $T$, Norris JR (eds) Methods in microbiology. London, Academic Press. 1979; 13: 31-49.

125. Ralovich B, Ewan EP, Emody L. Alteration of phage- and biotypes of Listeria strains. Acta Microbiol Hung 1986; 33: $19-26$.

126. Audurier A, Rocourt J, Courtieu AL. Phage typing systems for Listeria monocytogenes. In: Ivanov I (ed) Seventh international symposium on problems in listeriosis, Sofia, National Agroindustrial Union Center for Scientific Information. 108-121.

127. Bibb WF, Schwartz B, Gellin BG, Plikaytis BD, Weaver RE Analysis of Listeria monocytogenes by multilocus enzyme electrophoresis and application of the method to epidemiologic investigations. Int J Food Microbiol 1989; 8 233-239.

128. Fistrovicia E, Collins-Thompson DL. Use of plasmid profiles and restriction endonuclease digest in environmental studies of Listeria spp. from raw milk. Int $J$ Food Microbiol 1990; 10: 43-50.

129. Wilhelms D, Sandow D. Preliminary studies on monocine typing of Listeria monocytogenes strains. Acta Microbiol Hung 1989 ; 36: 235-238.

130. Pérez-Díaz JC, Vincente MF, Baquero F. Plasmids in Listeria. Plasmid 1982; 8: 112-118

131. Saunders NA, Ridley AM, Taylor AG. Typing of Listeria monocytogenes for epidemiological studies using DNA probes. Acta Microbiol Hung 1989; 36: 205-209.

132. McLauchlin J, Audurier A, Taylor AG. The evaluation of a phage-typing system for Listeria monocytogenes for use in epidemiological studies. J Med Microbiol 1986; 22 : 357-365.

133. Schlech WF. Listeriosis: epidemiology, virulence and the significance of contaminated foodstuffs. J Hosp Infect 1991; 19: 211-224.

134. Ciesielski CA, Hightower AW, Parsons SK, Broome CV. Listeriosis in the United States: 1980-1982. Arch Intern Med 1988; 148: 1416-1419.

135. Frederiksen B, Samuelsson S. Feto-maternal listeriosis in Denmark 1981-1988. J Infect 1992; 24: 277-287.

136. Newton L, Hall SM, McLauchlin J. Listeriosis surveillance 1992. Commun Dis Rep CDR Rev 1993; 3: R144-R146.

137. McLauchlin J, Hall SM, Velani SK, Gilbert RJ. Human listeriosis and paté: a possible association. BMJ 1991; 303: 773-775.

138. Schlech WF, Lavigne PM, Bortolussi RA. Epidemic listeriosis-evidence for transmission by food. $N$ Engl $J$ Med 1983; 308: 203-206.

139. Flemming DW, Cochi SL, MacDonald KL et al. Pasteurized milk as a vehicle of infection in an outbreak of listeriosis. $N$ Engl J Med 1985; 312: 404- 407.

140. Bille J, Rocourt J, Mean F. Epidemic food borne listeriosis in western Switzerland. 28th ICAAC 1988: abstract no. 1107.

141. Schwartz B, Hexter D, Broome CV et al. Investigation of an outbreak of listeriosis: new hypotheses for the etiology of epidemic Listeria monocytogenes infections. $J$ Infect Dis $1989 ; 159: 680-685$.

142. Schwartz B, Ciesielski CA, Broome CV et al. Association of sporadic listeriosis with consumption of uncooked hot dogs and undercooked chicken. Lancet 1988; 2: 779-782.

143. Bannister BA. Listeria monocytogenes meningitis associated with eating soft cheese. $J$ Infect $1987 ; 15: 165-168$.

144. Kerr KG, Dealler SF, Lacey RW. Materno-fetal listeriosis from cook-chill and refrigerated food. Lancet 1988; 2 : 1133.

145. Azadian BS, Finnerty GT, Pearson AD. Cheese-borne Listeria meningitis in an immunocompetent patient. Lancet 1989; 1: 322-323.

146. Morris IJ, Ribeiro CD. The occurrence of Listeria species in pâté: the Cardiff experience 1989. Epidemiol Infect 1991; 107: $111-117$

147. Pini PN, Gilbert RJ. The occurrence in the UK of Listeria species in raw chickens and soft cheeses. Int $J$ Food Microbiol 1988; 6: 317-326.

148. MacGowan AP, Bowker K, McLauchlin J, Bennett PM, Reeves DS. The occurrence and seasonal changes in the isolation of Listeria spp. in shop bought food stuffs, human faeces, sewage and soil from urban sources. Int $J$ Food Microbiol (in press).

149. Breer C, Schopfer K. Listeria and food. Lancet 1988; 2: 1022.

150. Sepp AH, Roy TE. Listeria monocytogenes infections in metropolitan Toronto: a clinicopathological study. Can Med Ass $J 1963 ; 88$ : 549-561.

151. McLauchlin J. Human listeriosis in Britain, 1967-1985, a summary of 722 cases. 2. Listeriosis in non-pregnant individuals, a changing pattern of infection and seasonal incidence. Epidemiol Infect 1990; 104: 191-201.

152. Newton L, Hall SM, Pelevin M, McLauchlin J. Listeriosis surveillance: 1990. Commun Dis Rep CDR Rev 1991; 1: R110-R143.

153. McLauchlin J. Human listeriosis in Britain, 1967-85, a summary of 722 cases. 1. Listeriosis during pregnancy and in the newborn. Epidemiol Infect 1990; 104: 181-189.

154. Larsson S. Epidemiology of listeriosis in Sweden 1958-1974. Scand J Infect Dis 1979; 11: 47-54.

155. Nieman RE, Lorber B. Listeriosis in adults: a changing pattern. Report of eight cases and review of the literature, 1968-1978. Rev Infect Dis 1980; 2: 207-227.

156. Pollock SS, Pollock TM, Harrison MJG. Infection of the central nervous system by Listeria monocytogenes: a review of 54 adult and juvenile cases $Q J$ Med 1984; 53: 331-340.

157. Louria DB, Blevins A, Armstrong D. Listeria infections. Ann NY Acad Sci 1970; 174: 545-551.

158. Samra Y, Hertz M, Altmann G. Adult Listeriosis--a review of 18 cases, Postgrad Med J 1984; 60: 267-269.

159. Jurado RL, Farley MM, Pereira E et al. Increased risk of meningitis and bacteremia due to Listeria monocytogenes in patients with human immunodeficiency virus infection. Clin Infect Dis 1993; 17: 224-227.

160. Bo Hansen P, Jensen TH, Lykkegaard S, Kristensen HS. Listeria monocytogenes meningitis in adults. Sixteen consecutive cases 1973-1982. Scand J Infect Dis 1987: 19. $55-60$.

161. MacNair DR, White JE, Graham JM. Ampicillin in the treatment of Listeria monocytogenes meningitis. Lancet, $1968 ; 1: 16-18$

162. Lavetter A, Leedom JM, Mathies AW, Ivler D, Wehrle PF. Meningitis due to Listeria monocytogenes. A review of 25 cases. $N$ Engl J Med 1971; 285 : 598-603.

163. Larsson S, Cronberg, S, Winblad S. Clinical aspects on 64 cases of juvenile and adult listeriosis in Sweden. Acta Med Scand 1978; 204: 503-508

164. Cherubin CE, Appleman MD, Heseltine PN, Khayr W, Stratton $\mathrm{CW}$. Epidemiological spectrum and current treatment of listeriosis. Rev Infect Dis 1991; 13: 1108-1114

165. Moellering RC, Medoff G, Leech I, Wennersten C, Kunz LJ. Antibiotic synergism against Listeria monocytogenes. Antimicrob Agents Chemother 1972; 1: 30-34.

166. MacGowan AP. Holt HA. Reeves DS. In-vitro synergy testing of nine antimicrobial combinations against Listeria monocytogenes. J Antimicrob Chemother 1990; 25: 561-566.

167. Poyart-Salmeron C, Carlier C. Trieu-Cuot P, Courtieu A-L. Courvalin P. Transferable plasmid-mediated antibiotic 
resistance in Listeria monocytogenes. Lancet 1990; 335 : $1422-1426$.

168. MacGowan AP, Reeves DS, McLauchlin J. Antibiotic resistance of Listeria monocytogenes. Lancet 1990; 336: 513-514.

169. Trautmann M, Wagner J, Chahin M, Weinke T. Listeria meningitis: report of ten recent cases and review of current therapeutic recommendations. J Infect 1985; 10: $107-114$.

170. Stamm AM, Dismukes WE, Simmons BP et al. Listeriosis in renal transplant recipients: report of an outbreak and review of 102 cases. Rev Infect Dis 1982; 4: 665-682.
171. Cherubin CE. Questions about Listeria monocytogenes susceptibility testing. Infect Dis Newsletter 1992; 11: 19-21.

172. Cherubin CE, Marr JS, Sierra MF, Becker S. Listeria and gram-negative bacillary meningitis in New York City, 1972-1979. Frequent causes of meningitis in adults. $A m J$ Med 1981; 71: 199-209.

173. McLauchlin J, Audurier A, Taylor AG. Treatment failure and recurrent listeriosis. J Antimicrob Chemother 1991; 27: $851-857$.

174. Bouvet E, Suter F, Gibert C, Witchitz JL, Bazin C, Vachon F. Severe meningitis due to Listeria monocytogenes. A review of 40 cases in adults. Scand J Infect Dis 1982;14:267-270. 